\title{
Projections of air pollutant emissions and its impacts on regional air quality in China in $\mathbf{2 0 2 0}$
}

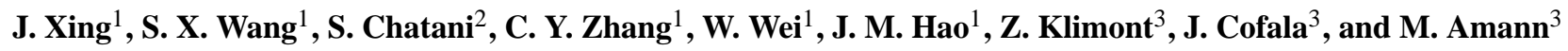 \\ ${ }^{1}$ Department of Environmental Science and Engineering, and State Key Joint Laboratory of Environment Simulation and \\ Pollution Control, Tsinghua University, Beijing 100084, China \\ ${ }^{2}$ Technology and Systems Analysis Laboratory, Toyota Central R\&D Labs., Inc, Nagakute, Aichi 480-1192, Japan \\ ${ }^{3}$ Atmospheric Pollution \& Economic Development, International Institute for Applied Systems Analysis, 2361 Laxenburg, \\ Austria
}

Received: 18 August 2010 - Published in Atmos. Chem. Phys. Discuss.: 9 November 2010

Revised: 20 March 2011 - Accepted: 28 March 2011 - Published: 4 April 2011

\begin{abstract}
Anthropogenic emissions of air pollutants in China influence not only local and regional environments but also the global atmospheric environment; therefore, it is important to understand how China's air pollutant emissions will change and how they will affect regional air quality in the future. Emission scenarios in 2020 were projected using forecasts of energy consumption and emission control strategies based on emissions in 2005, and on recent development plans for key industries in China. We developed four emission scenarios: REF[0] (current control legislations and implementation status), $\mathrm{PC}[0]$ (improvement of energy efficiencies and current environmental legislation), $\mathrm{PC}[1]$ (improvement of energy efficiencies and better implementation of environmental legislation), and $\mathrm{PC}$ [2] (improvement of energy efficiencies and strict environmental legislation). Under the REF[0] scenario, the emission of $\mathrm{SO}_{2}, \mathrm{NO}_{\mathrm{x}}, \mathrm{VOC}$ and $\mathrm{NH}_{3}$ will increase by $17 \%, 50 \%, 49 \%$ and $18 \%$ in 2020 , while $\mathrm{PM}_{10}$ emissions will be reduced by $10 \%$ over East China, compared to that in 2005. In PC[2], sustainable energy polices will reduce $\mathrm{SO}_{2}, \mathrm{NO}_{\mathrm{x}}$ and $\mathrm{PM}_{10}$ emissions by $4.1 \mathrm{Tg}$, $2.6 \mathrm{Tg}$ and $1.8 \mathrm{Tg}$, respectively; better implementation of current control policies will reduce $\mathrm{SO}_{2}, \mathrm{NO}_{\mathrm{x}}$ and $\mathrm{PM}_{10}$ emission by $2.9 \mathrm{Tg}, 1.8 \mathrm{Tg}$, and $1.4 \mathrm{Tg}$, respectively; strict emission standards will reduce $\mathrm{SO}_{2}, \mathrm{NO}_{\mathrm{x}}$ and $\mathrm{PM}_{10}$ emissions by $3.2 \mathrm{Tg}, 3.9 \mathrm{Tg}$, and $1.7 \mathrm{Tg}$, respectively. Under the PC[2] scenario, $\mathrm{SO}_{2}$ and $\mathrm{PM}_{10}$ emissions will decrease by $18 \%$ and $38 \%$, while $\mathrm{NO}_{\mathrm{x}}$ and VOC emissions will increase by $3 \%$ and $8 \%$, compared to that in 2005. Future air quality in China was simulated using the Community Multi-scale Air Quality Model (CMAQ). Under REF[0] emissions, compared to
\end{abstract}

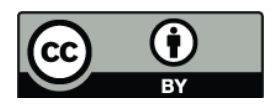

Correspondence to: $\mathrm{S}$. X. Wang (shxwang@tsinghua.edu.cn)
2005, the surface concentrations of $\mathrm{SO}_{2}, \mathrm{NO}_{2}$, hourly maximum ozone in summer, $\mathrm{PM}_{2.5}$, total sulfur and nitrogen depositions will increase by $28 \%, 41 \%, 8 \%, 8 \%, 19 \%$ and $25 \%$, respectively, over east China. Under the $\mathrm{PC}[2]$ emission scenario, the surface concentrations of $\mathrm{SO}_{2}, \mathrm{PM}_{2.5}$, total sulfur depositions will decrease by $18 \%, 16 \%$ and $15 \%$, respectively, and the surface concentrations of $\mathrm{NO}_{2}$, nitrate, hourly maximum ozone in summer, total nitrogen depositions will be kept as 2005 level, over east China. The individual impacts of $\mathrm{SO}_{2}, \mathrm{NO}_{\mathrm{x}}, \mathrm{NH}_{3}, \mathrm{NMVOC}$ and primary PM emission changes on ozone and $\mathrm{PM}_{2.5}$ concentrations have been analyzed using sensitivity analysis. The results suggest that $\mathrm{NO}_{\mathrm{x}}$ emission control need to be enhanced during the summertime to obtain both ozone and $\mathrm{PM}_{2.5}$ reduction benefits. $\mathrm{NH}_{3}$ emission controls should also be considered in order to reduce both nitrate concentration and total nitrogen deposition in the future.

\section{Introduction}

With the fast growth of the domestic economy and urbanization in China, the emissions of air pollutants from coal combustion, industrial production, and transport have been increasing at an unprecedented rate over the last decade. From 1995 to 2005, the annual growth rates of energy consumption, cement production, steel production, and the vehicle population, were $10 \%, 24 \%, 12 \%$, and $10 \%$, respectively. The observations from satellite remote sensing indicate that $\mathrm{NO}_{\mathrm{x}}$ emissions in the Central and East China have accelerated by a factor of 2 during 2000-2006 (Richter et al., 2005). There is evidence that anthropogenic emissions of air pollutants in China are influencing not only local and regional,

Published by Copernicus Publications on behalf of the European Geosciences Union. 
but also the global atmospheric environment (Wild and Akimoto, 2001; Liang et al., 2004; Dickerson et al., 2007). A better understanding of the emissions of air pollutants and their impact on air quality is therefore of great interest.

In 2009, the total energy consumption in China reached 3.1 billion tons of coal equivalents (tce), of which $69 \%$ is from coal (NBSC, 2010). China has overtaken the United States to become the world's largest energy user. What is more important is that the growth of energy consumption will continue into future because the energy consumption on a per capita basis is still only about one-third of the OECD average. Therefore, there are strong indications that emissions of air pollutants will keep increasing in the next decade. Future changes in air quality will be affected strongly by the expected changes in anthropogenic emissions, which are controlled by economic growth, environmental policy, and the future implementation of emissions controls. In light of this situation, the projections of future emissions are essential to designing cost-effective mitigation strategies and to understanding how the emissions affect the future air quality in China and Asia (Dentener et al., 2006; Unger et al., 2006).

Projections of Chinese (as part of Asia) emissions from fuel combustion and industrial sources have been made by van Aardenne et al. (1999) for $\mathrm{NO}_{\mathrm{x}}$, Streets and Waldhoff (2000) for $\mathrm{SO}_{2}, \mathrm{NO}_{\mathrm{x}}$, and $\mathrm{CO}$, Klimont et al. (2001) for $\mathrm{SO}_{2}, \mathrm{NO}_{\mathrm{x}}, \mathrm{NH}_{3}$, and $\mathrm{NMVOC}$, and Ohara et al. (2007) for $\mathrm{SO}_{2}, \mathrm{NO}_{\mathrm{x}}, \mathrm{CO}, \mathrm{NMVOC}$, black carbon (BC), and organic carbon (OC). Some studies have also forecast surface ozone levels over East Asia for the year 2020, indicating that $\mathrm{NO}_{\mathrm{x}}$ $\left(\mathrm{NO}_{\mathrm{x}}=\mathrm{NO}+\mathrm{NO}_{2}\right)$ and ozone would be a potential issue (Yamaji et al., 2008). These early projections suffered from poor data availability and were too optimistic about the pace of the introduction and effectiveness of environmental legislation. These projections also underestimated the economic growth experienced in the last decade in China (Klimont et al., 2009).

Based on the most recent development plan for key industries and on new information on local emission factors in China, this paper presents possible emission scenarios for $\mathrm{SO}_{2}, \mathrm{NO}_{\mathrm{x}}$, non-methane volatile organic compounds (NMVOCs), $\mathrm{NH}_{3}$ and primary particles (PM), and the potential impacts of emission changes on the regional air quality in China for the year 2020. Simulations on 2005 baseline and 2020 future emission scenarios have been conducted and analyzed using the Community Multi-scale Air Quality Model (CMAQ) for four months (January, April, July, and October). The next section describes the methodology used for the energy consumption forecast, the air pollution control legislation considered and the corresponding future emission scenarios. Section 3 presents the model output surface concentrations of $\mathrm{SO}_{2}, \mathrm{NO}_{2}$, fine particles, ozone, total sulfur and nitrogen deposition based on emissions in 2005 (the base year) and in 2020. Conclusions and recommendations for future air pollution control policies are provided in Sect. 4.

\section{Projection of $\mathrm{SO}_{2}, \mathrm{NO}_{\mathrm{x}}, \mathrm{PM}, \mathrm{NMVOC}$ and $\mathrm{NH}_{3}$ emissions in China}

The regions studied covered 31 Provinces, autonomous regions and municipalities over mainland China. Hong Kong, Macao and Taiwan were not included. Their emissions in 2020 are assumed as same as the 2005 baseline scenario, which are taken from the INDEX-B datasets (Zhang et al., 2009). $\mathrm{SO}_{2}, \mathrm{NO}_{\mathrm{x}}$, and $\mathrm{PM}$ with different size fractions (TSP, $\mathrm{PM}_{10}$, and $\mathrm{PM}_{2.5}$ ), NMVOC and $\mathrm{NH}_{3}$ were the targeted pollutant species. All data were at the provincial level. For a given Province $i$, year $y$, and pollutant $n$ considered in this paper, the emissions were calculated using the following equations:

$$
\begin{aligned}
E_{n, y} & =\sum_{i, k, l} A_{i, k, l, y} \sum_{m}\left[e f_{i, k, l, n}\left(1-\eta_{i, k, m, n}\right) X_{i, k, l, m, y}\right] \\
& (0<X \leq 1) \\
E_{n, y} & =\sum_{i, k, l} A_{i, k, l, y} e f_{i, k, l, n}(X=0)
\end{aligned}
$$

where, $i$ represents the Province (administrative region); $k$ represents the economic sector or combustion technology type; $l$ represents the fuel type (if relevant for a specific $k$ ); $m$ represents the abatement technology type; $E$ is the national annual emissions; $A$ is the activity level (e.g. fuel consumption, industrial production, amount of biomass burned on-field); ef is the uncontrolled emission factor; $\eta$ is the reduction efficiency of the abatement technology; and $X$ is the penetration of the abatement measure $m$ expressed as a percentage of total activity $A$.

To improve the emission estimates, data for emission factors are collected from the field measurements of Tsinghua University and other published results, as described in Sect. 2.2. Unit-based methodology is applied to estimate emissions from large point sources including coal-fired power plants, iron and steel plants, and cement plants (Zhao et al., 2008; Lei et al., 2008). Detailed local emission information aggregated from the bottom-up investigation of individual power plants, heating boilers, and industries in Beijing, Yangtze River Delta and Pearl River Delta are also incorporated into the national emission inventory ( $\mathrm{Li}$ et al., 2008; Zheng et al., 2009; Wang et al., 2010). A detailed description about the 2005 base year emission inventory is given in Xing et al. (2010).

\subsection{Projection of energy consumption}

The energy consumption level was estimated in collaboration between the research groups at International Institute for Applied Systems Analysis (IIASA) in Laxenburg (Austria), Tsinghua University and Energy Research Institute (ERI) in Beijing (China) (Amann et al., 2008).

The new projection are based in the provincial level, reflects current Chinese expectations with regard to the 
population projections from the National Population Development Strategy and the national development targets for renewable energy sources in the "11th Five-Year Plan". The energy forecast (i.e., energy demand, energy efficiency estimation and technology selection) were estimated by IPACAIM/local model developed by ERI (Jiang and Hu, 2006; Jiang et al., 2009), a bottom-up model with sectors classification and more than 100 technologies. The model searches for the least-cost technology mix to meet the given energy service demand (including five major sectors such as industry, agriculture, service, residence, and transportation, which are further divided into sub-sectors). The up-to-date information on these technologies was collected from large number of literature. The details about the forecast of future activities are given as follows.

\section{Population}

The national population projections for the year 2010 to 2020 were completely adopted from the Research Report on National Population Development Strategy (NPDSR, 2007), i.e., 1.36 and 1.45 billion in 2010 and 2020. The provincial populations were forecasted using the historical data from 1995 to 2005 through the logistic regression method. Minor adjustment was conducted to make the total of provincial populations to be consistent with the national population.

\section{Gross Domestic Product (GDP, in year 2000 prices)}

The provincial GDP growth rates from 2006 to 2010 were attained from the 11th five-year plan enacted by the local provincial governments (http://www.gov.cn/ test/2006-07/25/content_344715.htm, in Chinese). The provincial GDP growth rates from 2010 to 2020 were forecast using the logistic regression method according to the historical data from 1996 to 2005 . The average annual growth rate of national GDP was calculated from the provincial data, which was in line with the Reference Scenario in International Energy Agency (IEA) report, i.e., 7.7\% during 2005-2015 and 6\% over 20152020 (IEA, 2007).

\section{Activity data}

We developed two energy scenarios, a reference scenario (REF) which was based on current development trends, and a policy scenario (PC) which assumed that more sustainable energy development strategies would be adopted in the future. Baseline scenario gives a basic trend to describe future economic activities. Only existing legislations on energy and environment will be implemented. Various energy and emission control policies are assumed for the policy scenario. In the policy scenario, policies on energy conservation, renewable energy will be widely adopted by both regulation and financial incentives. Economic structure change is also considered. However, the application of abatement technologies is assumed same across all provinces in this study. Scenario assumptions and key macroeconomic parameters are given in Table 1.

Projection of electricity generation considers the use of different energy and technologies. The development of renewable energy sources followed the national targets in the 11th Five-Year Plan (NDRC, 2008a). The future development of hydro power, nuclear power and other renewable resources, the improvement of thermal efficiency, as well as the fuel structure have been considered in the model. The annual nuclear generation will be $260-280$ billion $\mathrm{kWh}$ in 2020, according to the 'long-term development plan of nuclear power' reported by NDRC (NDRC, 2007). The hydro power will be developed in west China. The west-east gas transmitting project will promote natural gas power plants in the future. But the coal will still be the dominant fuel, accounting for $95.3 \%$ and $93.6 \%$ of thermal power plants in 2020REF and 2020PC, respectively. The power generation technologies include sub-critical units with a thermal efficiency of 30-36\%, super-critical units with a thermal efficiency of $41 \%$, ultra-supercritical units with a thermal efficiency of 43\%, and IGCC (Integrated Gasification Combined Cycle) with a thermal efficiency of 45-55\%. Before 2005, sub-critical units are the dominant technology. Super-critical units are widely applied since 2005 . Ultra-supercritical units and IGCC will be promoted in the next five years. Closing the small units is another policy to improve the energy efficiency of power sector. Considering the promotion new technologies, the thermal efficiencies are assumed to increase to $37.5 \%$ in $2020 \mathrm{REF}$ and $38.5 \%$ in $2020 \mathrm{PC}$ scenario.

Primary energy demand is related to energy service demand of each subsector driven by the socio-economic growth (i.e., population, GDP, lifestyle, etc), and also influenced by the technology progress, energy efficiency as well as the transition of energy and industry structure.

For industrial sectors, in general, the comprehensive energy consumption will reach the levels of developed countries in 2020. The comprehensive energy consumption in steel production, non-ferrous metal smelting, ethylene, ammonia synthesis, and cement production will decrease by $18 \%, 7 \%, 29 \%, 27 \%$ and $33 \%$ respectively in 2020 , compared to that in 2000, according to the "energy-saving in long-term and special program" reported by NRDC (NRDC, 2004). The ratio of coal in energy structure will decrease, and the ratio of natural gas and electricity will slightly increase. The ratio of Circulating Fluidized-Bed (CFB) boiler used in industry will increase from $10 \%$ in 2005 to $15 \%$ in 2020, since CFB is more efficient and emits less $\mathrm{SO}_{2} / \mathrm{NO}_{\mathrm{x}}$ than grate boiler.

For domestic sources, along with the increase of the per capita income of rural residents, cleaner fuel will be promoted. In developed regions (e.g., Beijing, Tianjin, Shanghai), coal will be replaced by nature gas and electricity. In less developed regions where biomass is the major energy type, the biomass is going to be replaced by coal or gas and 
Table 1. Key parameters used in the development of energy scenarios.

\begin{tabular}{|c|c|c|c|c|}
\hline \multicolumn{2}{|r|}{ Scenario } & 2005 & Reference Scenario [REF] & Policy Scenerio [PC] \\
\hline \multirow[t]{3}{*}{$\begin{array}{l}\text { Power plants } \\
(\mathrm{PP})\end{array}$} & $\begin{array}{l}\text { Electricity production } \\
\text { (billion } \mathrm{kW} \cdot \mathrm{h} \text { ) }\end{array}$ & 2055 & $\begin{array}{l}5226 \\
\text { (annual growth rate: } 6.4 \% \text { ) }\end{array}$ & $\begin{array}{l}4759 \\
\text { (annual growth rate: } 5.8 \% \text { ) }\end{array}$ \\
\hline & Thermal efficiency & $32.0 \%$ & $37.5 \%$ & $38.5 \%$ \\
\hline & $\begin{array}{l}\text { Percentage of coal } \\
\text { power }\end{array}$ & $95.2 \%$ & $95.3 \%$ & $93.6 \%$ \\
\hline \multirow[t]{2}{*}{ Industry (IND) } & $\begin{array}{l}\text { Energy consumption } \\
(\mathrm{PJ})\end{array}$ & 30678 & $\begin{array}{l}70528 \\
\text { (annual growth rate: } 4.1 \% \text { ) }\end{array}$ & $\begin{array}{l}66155 \\
\text { (annual growth rate: } 3.5 \% \text { ) }\end{array}$ \\
\hline & $\begin{array}{l}\text { Energy structure (ratio } \\
\text { of coal, oil, gas and } \\
\text { electricity) }\end{array}$ & $\begin{array}{l}59 \%, 10 \%, \\
11 \% \text { and } 20 \%\end{array}$ & $57 \%, 9 \%, 14 \%$, and $20 \%$ & $54 \%, 9 \%, 16 \%$, and $21 \%$ \\
\hline \multirow[t]{2}{*}{$\begin{array}{l}\text { Domestic } \\
\text { (DOM) }\end{array}$} & $\begin{array}{l}\text { Energy consumption } \\
(\mathrm{PJ})\end{array}$ & 16333 & $\begin{array}{l}21786 \\
\text { (annual growth rate: } 1.9 \% \text { ) }\end{array}$ & $\begin{array}{l}20438 \\
\text { (annual growth rate: } 1.5 \% \text { ) }\end{array}$ \\
\hline & $\begin{array}{l}\text { Energy structure (ratio } \\
\text { of coal, gas, biomass, } \\
\text { electricity and heat) }\end{array}$ & $\begin{array}{l}25 \%, 9 \%, 47 \%, \\
14 \% \text { and } 4 \%\end{array}$ & $\begin{array}{l}16 \%, 11 \%, 41 \%, 25 \% \text { and } \\
7 \%\end{array}$ & $\begin{array}{l}14 \%, 12 \%, 41 \%, 26 \% \text { and } \\
7 \%\end{array}$ \\
\hline \multirow[t]{2}{*}{$\begin{array}{l}\text { Transport } \\
\text { (TRA) }\end{array}$} & $\begin{array}{l}\text { Vehicle population of } \\
\text { truck, car, and motor } \\
\text { cycle (million) }\end{array}$ & $\begin{array}{l}9.55,21.33 \text { and } \\
75.8\end{array}$ & \multicolumn{2}{|c|}{$21.29,136.7$ and 98.0} \\
\hline & $\begin{array}{l}\text { Fuel economy of car, } \\
\text { truck, motorcycle, and } \\
\text { agriculture transport } \\
\text { machine }\end{array}$ & & $\begin{array}{l}\text { Increase by } 30 \%, 25 \% \text {, } \\
30 \% \text { and } 15 \%\end{array}$ & $\begin{array}{l}\text { Increase by } 40 \%, 36 \% \text {, } \\
36 \% \text { and } 23 \%\end{array}$ \\
\hline
\end{tabular}

electricity. According to the "energy-saving in long-term and special program", energy saving in constructions, commercial and residential sectors has also been considered, including design of energy saving building and energy-saving appliances promotion.

For mobile sources, the vehicle populations of truck, car, and motor cycle, as well as passenger or freight traffic volume of inland water and railroad, are driven by the socioeconomic growth. The energy consumptions in transportation sector are also influenced by the changes of vehicle types and fuel economy. Those parameters are mainly referred to He et al. (2005), Wang et al. (2007) and IEA (2007). There is a continuous growth trend of larger trucks for long-distance freight transportation and a trend in rapid growth in light and mini vehicle fleets, while the medium-size trucks will decline greatly. Besides, the share of diesel vehicles in the Chinese vehicle fleet will increase, since diesel vehicles have better fuel economy than gasoline vehicles. Passenger car ownership will experience exploding growth due to rapid growth of private vehicles. To improve the fuel economy, Chinese government released a series of energy consumption standards for vehicles, such as the "limits of fuel consumption for passenger cars" in 2004, "limits of fuel consumption for light duty commercial vehicles" in 2007, "low-speed goods vehicles - limits and measurement methods for fuel consumption" and "Tri-wheel vehicles - limits and measurement methods for fuel consumption" in 2008. Fuel economy of car, truck, motorcycle, and agriculture transport machine will increase by $30 \% / 40 \%, 25 \% / 36 \%, 30 \% / 36 \%$, and $15 \% / 23 \%$ in 2020REF/PC scenarios, compared to that in 2005. According to the "energy-saving in long-term and special program" reported by NRDC (2004), the comprehensive energy consumption in railroad will reduce from $9.65 \mathrm{tce} /(\mathrm{Mt} \mathrm{km})$ in 2005 to 9.00 tce/(Mt km) in 2020.

The industrial process sector is forecast based on the population and GDP projections. The logistic model was used to forecast the total industrial production in China. The industrial production was considered to be related to the industrial development level represented by the industrial added value (Jiang and $\mathrm{Hu}, 2006$ ). The model parameters were solved from the historical data from 1996-2005. The quantity of provincial industrial product was forecast by their respective ratios in the total industrial product. The renovation of technology has been considered. According to the 'Suggestions on speeding up the cement industry structure adjustment' released by NRDC (2006), the advanced precalcining kilns will take up $70 \%$ of total cement production by 2010 . The units with out-of-date technology (i.e., Earth kiln) in lime plants 
will be phased out (Liu and Yin, 2004; CLA, 2005). Chinese government has announced to phase out the indigenous coke production by 2010. Advanced technologies in nitric acid and sulfur acid plants are promoted in the future.

In 2020, total energy consumption is projected to be 134165 PJ under the REF scenario and 122493 PJ under the PC scenario, respectively. Compared to 2005, the energy consumption of power plants, industry and transportation in 2020 would increase sharply, as shown in Fig. 1a. From 2005 to 2020 , energy use by power plants will increase by $117 \%$ under the REF scenario and $92 \%$ under the PC scenario, respectively. Jiangsu, Guangdong and Shandong are top power generation Provinces. From 2005 to 2020, energy consumption by industry will increase $82 \%$ under the REF scenario and $68 \%$ under the PC scenario, respectively. Shandong, Hebei and Shanxi are the top three industrial Provinces. Energy consumption by on-road transport in 2020 will increase $203 \%$ under the REF scenario and $190 \%$ under the PC scenario compared to that in 2005. Guangdong, Shandong and Beijing consume up to $30 \%$ of the total transport energy consumption in 2020. The sectoral fuel use by each Province and each scenario is given in Table 2.

The change of the fuel structure in each sector has also been considered in this study, as shown in Fig. 1b. Although coal will still be the most important fuel for power plants and industries, the percentage of oil and gas will grow at a much faster rate. Under the REF and PC scenarios, the annual growth rate of oil is 1.28 and 1.81 times that of coal used in power plants and 1.88 and 1.76 times that of coal used in industry, respectively. The percentages of the total energy consumption for coal, oil, gas and bio-fuel are $66 \%, 13 \%$, $10 \%$ and $10 \%$ in $2005,68 \%, 16 \%, 10 \%$ and $7 \%$ in the REF scenario, and $65 \%, 17 \%, 11 \%$ and $7 \%$ in the PC scenario.

\subsection{Uncontrolled emission factors}

Uncontrolled emission factors were obtained from recent references, which reported measurements from Chinese sources. The literature was thoroughly searched for published data for emission factors from domestic field measurements at power plants (Tian, 2003; Zhu et al., 2004; Yi et al., 2006; Zhao et al., 2008, 2011), industrial boilers (Wang et al., 2008; Li et al., 2007; Lei et al., 2008), and biomass and bio-fuel burning (Li et al., 2007, 2009). A survey of the open burning of crop residues was conducted (Wang et al., 2008). Data on NMVOC emission characteristics measured in China were also collected, which included stoves burning bio-fuel and coal, road transportation, certain industrial and domestic sectors using solvent, fugitive emissions from oil exploration and distribution, and open burning of biomass (Wei et al., 2008; Wang et al., 2009). A dataset of emission factors has been documented based on these papers. All emission factors, and other assumptions used in this study can be viewed at the on-line version of the GAINS-Asia model (http://gains.iiasa.ac.at/), while a more detailed description is
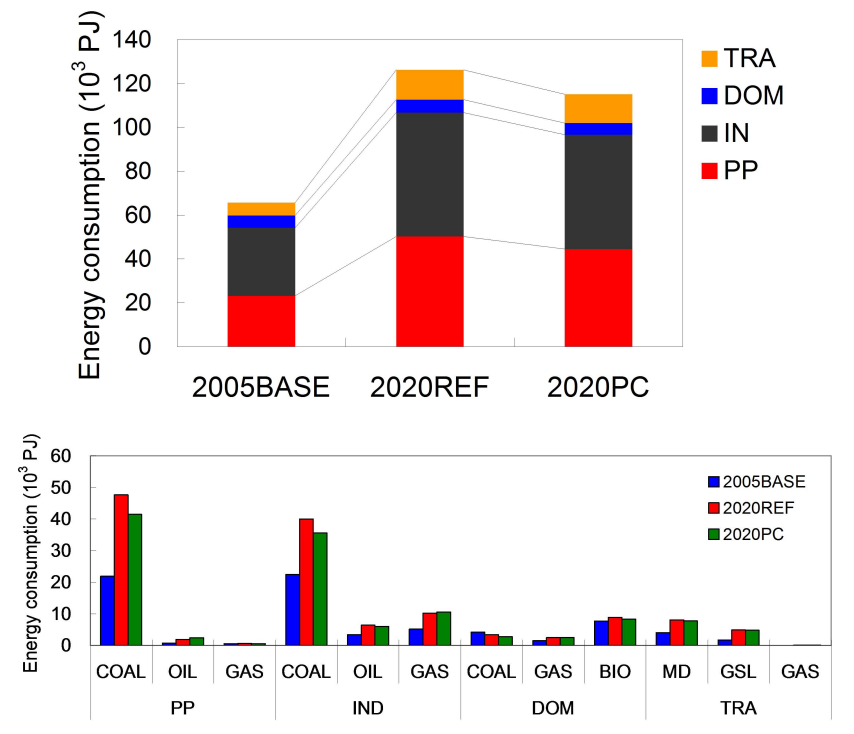

Fig. 1. Energy consumption in 2005 and 2020 (Sector: PP - Power plants; IND - Industry; DOM - Domestic; TRA - Transport; Fuel: COAL - raw coal, washed coal, coke, briquettes; OIL - fuel oil, diesel, kerosene, raw oil, gasoline, liquefied petroleum gas (LPG); GAS - nature gas, coal gas, other gas; BIO - straw, brushwood; MD - diesel, kerosene, raw oil; GSL - gasoline). (a) Energy consumption by sectors in 2005 and 2020. (b) Energy consumption by fuel type in 2005 and 2020.

also available in the methodology document (Amann et al., 2008).

\subsection{Air pollution control legislation}

Three potential air pollution control scenarios were designed for 2020, including a baseline scenario, a better implementation scenario, and a strict policy scenario. The baseline scenario (strategy-[0]) assumed that all current legislation and the implementation status of proposed legislation would be followed during 2005-2020. The better implementation scenario (strategy-[1]) considered the enhanced enforcement of current legislation and planned air pollution control measures. The strict policy scenario (strategy-[2]) assumed strict control policies and that more advanced control technologies would be implemented during 2005-2020. Tables 3-5 summarizes the progress of alternative technologies on air pollution control measures under the various scenarios.

\subsubsection{Sulfur dioxides $\left(\mathrm{SO}_{2}\right)$}

Table 3 gives the penetration of $\mathrm{SO}_{2}$ control measures assumed under the three control scenarios. In strategy-[0], the most important $\mathrm{SO}_{2}$ control measure is the installation of flue gas desulfurization (FGD) in power plants. The Chinese government wants to reduce national $\mathrm{SO}_{2}$ emissions by $10 \%$ in 2010 on the basis of that in 2005. To achieve this goal, FGD devices are now being widely installed in coal-fired power 
Table 2. Sectoral fuel use by each Province in 2005 and 2020 scenarios (PJ).

\begin{tabular}{|c|c|c|c|c|c|c|c|c|c|c|c|c|c|c|c|}
\hline \multirow[b]{2}{*}{ Province } & \multicolumn{3}{|c|}{$\begin{array}{c}\text { Power } \\
\text { plant (PP) }\end{array}$} & \multicolumn{3}{|c|}{$\begin{array}{c}\text { Industrial } \\
\text { boiler (IND) }\end{array}$} & \multicolumn{3}{|c|}{$\begin{array}{l}\text { Domestic } \\
\text { (DOM) }\end{array}$} & \multicolumn{3}{|c|}{$\begin{array}{l}\text { On-road transport } \\
\text { (TRA_RD) }\end{array}$} & \multicolumn{3}{|c|}{$\begin{array}{l}\text { Non-road transport } \\
\text { (TRA_OTH) }\end{array}$} \\
\hline & 2005 & REF & $\mathrm{PC}$ & 2005 & REF & $\mathrm{PC}$ & 2005 & REF & $\mathrm{PC}$ & 2005 & REF & $\mathrm{PC}$ & 2005 & REF & $\mathrm{PC}$ \\
\hline Anhui & 700 & 1347 & 1195 & 799 & 1425 & 1315 & 756 & 617 & 562 & 99 & 229 & 218 & 128 & 164 & 162 \\
\hline Beijing & 224 & 372 & 330 & 588 & 1193 & 1102 & 304 & 280 & 263 & 185 & 893 & 866 & 32 & 39 & 39 \\
\hline Chongqing & 199 & 333 & 295 & 519 & 608 & 561 & 260 & 251 & 221 & 59 & 202 & 192 & 35 & 76 & 74 \\
\hline Fujian & 445 & 1410 & 1251 & 722 & 1599 & 1474 & 131 & 236 & 210 & 80 & 252 & 242 & 33 & 35 & 34 \\
\hline Gansu & 336 & 807 & 716 & 451 & 974 & 897 & 283 & 296 & 271 & 42 & 60 & 57 & 52 & 77 & 76 \\
\hline Guangdong & 1801 & 5019 & 4451 & 1459 & 2484 & 2282 & 589 & 679 & 649 & 426 & 1382 & 1326 & 92 & 122 & 119 \\
\hline Guangxi & 301 & 731 & 649 & 697 & 1956 & 1805 & 453 & 460 & 441 & 68 & 228 & 219 & 63 & 92 & 90 \\
\hline Guizhou & 673 & 909 & 807 & 548 & 1629 & 1501 & 523 & 613 & 548 & 55 & 151 & 144 & 30 & 47 & 46 \\
\hline Hainan & 74 & 235 & 208 & 85 & 173 & 160 & 164 & 136 & 128 & 19 & 76 & 72 & 8 & 11 & 10 \\
\hline Hebei & 1498 & 3199 & 2837 & 3238 & 5038 & 4653 & 815 & 781 & 711 & 231 & 675 & 647 & 223 & 271 & 268 \\
\hline Heilongjiang & 721 & 1096 & 972 & 926 & 949 & 876 & 476 & 365 & 347 & 97 & 225 & 216 & 67 & 95 & 94 \\
\hline Henan & 1640 & 3363 & 2983 & 1487 & 3247 & 2993 & 754 & 681 & 622 & 173 & 461 & 442 & 209 & 241 & 239 \\
\hline Hubei & 577 & 912 & 809 & 1175 & 1996 & 1842 & 728 & 591 & 540 & 102 & 252 & 241 & 94 & 137 & 134 \\
\hline Hunan & 390 & 1126 & 999 & 1182 & 1032 & 953 & 617 & 501 & 458 & 93 & 211 & 202 & 98 & 142 & 138 \\
\hline Inner Mongolia & 1346 & 4066 & 3607 & 970 & 2150 & 1983 & 476 & 690 & 622 & 78 & 210 & 201 & 59 & 64 & 64 \\
\hline Jiangsu & 2137 & 5325 & 4723 & 2218 & 2627 & 2421 & 769 & 593 & 561 & 199 & 660 & 635 & 141 & 144 & 141 \\
\hline Jiangxi & 392 & 922 & 818 & 521 & 1117 & 1030 & 278 & 245 & 221 & 60 & 196 & 187 & 53 & 77 & 76 \\
\hline Jilin & 539 & 519 & 461 & 902 & 1112 & 1027 & 532 & 483 & 439 & 72 & 161 & 155 & 46 & 54 & 54 \\
\hline Liaoning & 986 & 1731 & 1535 & 2185 & 2891 & 2669 & 609 & 753 & 682 & 153 & 394 & 378 & 80 & 112 & 110 \\
\hline Ningxia & 318 & 1036 & 919 & 186 & 82 & 75 & 85 & 110 & 99 & 20 & 66 & 62 & 16 & 17 & 17 \\
\hline Qinghai & 77 & 105 & 93 & 86 & 178 & 162 & 121 & 120 & 110 & 15 & 27 & 26 & 12 & 14 & 13 \\
\hline Shaanxi & 530 & 1699 & 1507 & 368 & 368 & 339 & 394 & 365 & 332 & 70 & 210 & 201 & 49 & 55 & 54 \\
\hline Shandong & 2198 & 4656 & 4129 & 3224 & 5592 & 5159 & 1533 & 1427 & 1314 & 273 & 956 & 917 & 244 & 284 & 278 \\
\hline Shanghai & 782 & 1514 & 1343 & 695 & 1019 & 939 & 106 & 98 & 92 & 98 & 289 & 278 & 16 & 14 & 13 \\
\hline Shanxi & 1395 & 2967 & 2632 & 1563 & 4634 & 4276 & 347 & 375 & 339 & 127 & 460 & 441 & 82 & 147 & 145 \\
\hline Sichuan & 640 & 761 & 675 & 784 & 1493 & 1375 & 1255 & 1068 & 1000 & 153 & 411 & 394 & 74 & 134 & 130 \\
\hline Tianjin & 366 & 426 & 378 & 552 & 1526 & 1408 & 121 & 105 & 98 & 66 & 213 & 206 & 27 & 36 & 35 \\
\hline Tibet & 0 & 0 & 0 & 0 & 0 & 0 & 8 & 8 & 0 & 10 & 39 & 37 & 3 & 1 & 1 \\
\hline Xinjiang & 319 & 678 & 601 & 815 & 2467 & 2280 & 256 & 301 & 270 & 66 & 158 & 152 & 32 & 48 & 47 \\
\hline Yunnan & 449 & 634 & 562 & 771 & 1746 & 1611 & 368 & 333 & 304 & 127 & 247 & 237 & 45 & 66 & 64 \\
\hline Zhejiang & 1098 & 2272 & 2015 & 1334 & 3263 & 3004 & 287 & 235 & 224 & 222 & 720 & 692 & 86 & 100 & 98 \\
\hline Total & 23151 & 50172 & 44501 & 31051 & 56570 & 52170 & 14397 & 13796 & 12680 & 3539 & 10712 & 10281 & 2228 & 2914 & 2861 \\
\hline
\end{tabular}

plants. In 2005 , only $15 \%$ of the power plants had FGD. By 2009, the percentage has increased to $71 \%$. Considering that all newly-built power plants will install FGD, and some of the older plants will be retired, the percentage will continue to increase during 2010-2020. We project that in 2020 , the power plants with FGD will account for $81 \%$, 95\% and $95 \%$ under strategy-[0], strategy-[1] and strategy-[2], respectively. Currently, there is no effective measure in place to control $\mathrm{SO}_{2}$ emissions from industrial boilers. In strategy[1], enforcement of legislation will be strengthened so that industries can meet the current emission standards, and 50\% of the coal used in industries will be low sulfur coal or briquette. In strategy-[2], 30\% of the industrial boilers will install FGD in order to meet emission standard. In all three strategies, Limestone Injection into Furnace (LIN) technology will be applied to all CFB Boiler. In the domestic sector, there are no control efforts being considered under baseline strategy-[0]. Under strategy-[1], we assume the application of low sulfur coal or briquette in domestic stoves will increase up to $80 \%$ in 2020 . Under strategy-[2], we assume that new emission standards will be implemented for small domestic boilers; therefore, $80 \%$ of domestic boilers will use low sulfur coal or briquette in 2020 .

Industry processes including cement plants, lime plants, coking plants and sinter plants are important $\mathrm{SO}_{2}$ sources as well. For cement plants, the units with out-of-date technology such as rotary kilns and vertical kiln will be shut down. As shown in Table 4, by 2020, the percentage of advanced precalcining kilns will increase to $91 \%$ in the cement industry, which decreases the $\mathrm{SO}_{2}$ emission factor (EF) by $53 \%$ compared to that in 2005. The lime plants using early kilns will decrease from $70 \%$ in 2005 to $13 \%$ in 2020 , while those using modern kilns will increase from $30 \%$ in 2005 to $87 \%$ in 2020. All the indigenous coke plants will also be closed before 2020. For sinter plants, desulfurization technology is not practical under strategy-[0] and strategy-[1]. In strategy-[2] we assume that from 2015, more effort will be made to improve the control technology used in sinter plants, and that EF will be decreased by $30 \%$ in 2020 compared to that in 2005. 
Table 3. Penetration of selected air pollution control measures assumed under three control scenarios.

\begin{tabular}{|c|c|c|c|c|c|c|}
\hline \multirow[b]{2}{*}{ Sector } & \multirow[b]{2}{*}{ Sub-sector } & \multirow[b]{2}{*}{ Control technology } & \multirow[b]{2}{*}{2005} & \multicolumn{3}{|c|}{2020 scenario } \\
\hline & & & & [0]-Baseline & [1]-Better implementation & [2]-Strict policy \\
\hline \multirow[t]{12}{*}{ Power plants } & Old units & $\mathrm{FGD}\left(\mathrm{SO}_{2}\right)$ & $15 \%$ & $45 \%$ & $85 \%$ & $85 \%$ \\
\hline & & $\mathrm{LNB}\left(\mathrm{NO}_{\mathrm{x}}\right)$ & $46 \%$ & $46 \%$ & $100 \%$ & $100 \%$ \\
\hline & New units & $\mathrm{FGD}\left(\mathrm{SO}_{2}\right)$ & & $100 \%$ & $100 \%$ & $100 \%$ \\
\hline & & $\mathrm{SCR}\left(\mathrm{NO}_{\mathrm{x}}\right)$ & & & $45 \%$ & $85 \%$ \\
\hline & & $\mathrm{LNB}\left(\mathrm{NO}_{\mathrm{x}}\right)$ & & $100 \%$ & $100 \%$ & $100 \%$ \\
\hline & Grate boiler & CYC(PM) & $40 \%$ & $40 \%$ & & \\
\hline & & WET(PM) & $60 \%$ & $60 \%$ & $100 \%$ & \\
\hline & & ESP(PM) & & & & $85 \%$ \\
\hline & & $\mathrm{FF}(\mathrm{PM})$ & & & & $15 \%$ \\
\hline & Pulverized & WET(PM) & $8 \%$ & & & \\
\hline & coal boiler & ESP(PM) & $92 \%$ & $85 \%$ & $85 \%$ & $85 \%$ \\
\hline & & $\mathrm{FF}(\mathrm{PM})$ & & $15 \%$ & $15 \%$ & $15 \%$ \\
\hline \multirow{9}{*}{$\begin{array}{l}\text { Industrial } \\
\text { combustion }\end{array}$} & Grate boiler & $\mathrm{FGD}\left(\mathrm{SO}_{2}\right)$ & & & & $30 \%$ \\
\hline & & $\mathrm{LSC}\left(\mathrm{SO}_{2}\right)$ & & & $50 \%$ & $50 \%$ \\
\hline & & $\mathrm{LNB}\left(\mathrm{NO}_{\mathrm{x}}\right)$ & & & & $32 \%$ \\
\hline & & CYC(PM) & $23 \%$ & $6 \%$ & & \\
\hline & & WET(PM) & $73 \%$ & $93 \%$ & $100 \%$ & $43 \%$ \\
\hline & & $\mathrm{FF}(\mathrm{PM})$ & & & & $57 \%$ \\
\hline & Circulating & $\mathrm{LIN}\left(\mathrm{SO}_{2}\right)$ & $100 \%$ & $100 \%$ & $100 \%$ & $100 \%$ \\
\hline & Fluidized-Bed & WET(PM) & $100 \%$ & $100 \%$ & $100 \%$ & $24 \%$ \\
\hline & (CFB) boiler & $\mathrm{FF}(\mathrm{PM})$ & & & & $76 \%$ \\
\hline \multirow[t]{5}{*}{ Domestic } & Stove & $\mathrm{LSC}\left(\mathrm{SO}_{2}\right)$ & & & $80 \%$ & $80 \%$ \\
\hline & Boiler & $\mathrm{LSC}\left(\mathrm{SO}_{2}\right)$ & & & & $80 \%$ \\
\hline & & CYC(PM) & $23 \%$ & $10 \%$ & & \\
\hline & & WET(PM) & $63 \%$ & $83 \%$ & $100 \%$ & $84 \%$ \\
\hline & & $\mathrm{FF}(\mathrm{PM})$ & & & & $16 \%$ \\
\hline \multirow[t]{25}{*}{ Transport } & Car-gasoline & Uncontrolled & $39 \%$ & & & \\
\hline & & EURO-I & $38 \%$ & & & \\
\hline & & EURO-II & $23 \%$ & $6 \%$ & $6 \%$ & $6 \%$ \\
\hline & & EURO-III & & $17 \%$ & $17 \%$ & $17 \%$ \\
\hline & & EURO-IV & & $78 \%$ & $78 \%$ & $13 \%$ \\
\hline & & EURO-V & & & & $65 \%$ \\
\hline & Car-diesel & Uncontrolled & $2 \%$ & & & \\
\hline & & EURO-I & $59 \%$ & & & \\
\hline & & EURO-II & $39 \%$ & $3 \%$ & $3 \%$ & $3 \%$ \\
\hline & & EURO-III & & $10 \%$ & $10 \%$ & $10 \%$ \\
\hline & & EURO-IV & & $87 \%$ & $87 \%$ & $11 \%$ \\
\hline & & EURO-V & & & & $76 \%$ \\
\hline & Trucks-diesel & Uncontrolled & $33 \%$ & & & \\
\hline & & EURO-I & $40 \%$ & & & \\
\hline & & EURO-II & $27 \%$ & $4 \%$ & $4 \%$ & $4 \%$ \\
\hline & & EURO-III & & $12 \%$ & $12 \%$ & $12 \%$ \\
\hline & & EURO-IV & & $11 \%$ & $11 \%$ & $11 \%$ \\
\hline & & EURO-V & & $73 \%$ & $73 \%$ & $73 \%$ \\
\hline & Agriculture, & Uncontrolled & $100 \%$ & $100 \%$ & $100 \%$ & \\
\hline & construction & EURO-I & & & & $13 \%$ \\
\hline & machine & EURO-II & & & & $12 \%$ \\
\hline & & EURO-III & & & & $41 \%$ \\
\hline & Inland water & Uncontrolled & $100 \%$ & $100 \%$ & $100 \%$ & \\
\hline & & EURO-I & & & & $13 \%$ \\
\hline & & EURO-II & & & & $32 \%$ \\
\hline
\end{tabular}

Notes: FGD - Flue Gas Desulfurization; LSC - low-sulfur coal; LIN - Limestone Injection into Furnace; SCR - Selective Catalytic Reduction; LNB - Low NO x burner; CYC mechanical dust collector; WET - wet dust collector; ESP - Electrostatic precipitation; FF - Fabric Filter. 
Table 4. Technology changes of selected industrial processes.

\begin{tabular}{llrr}
\hline Sector & Technology & 2005 & 2020 \\
\hline Power plants & Grate boiler & $3.9 \%$ & $1.7 \%$ \\
& Pulverized coal boiler & $96.1 \%$ & $98.3 \%$ \\
& & & \\
\hline Industry boiler & Grate boiler & $90 \%$ & $85 \%$ \\
& Circulating Fluidized & $10 \%$ & $15 \%$ \\
& -Bed (CFB) boiler & & \\
\hline Cement plant & Rotary kiln & $4 \%$ & $1 \%$ \\
& Vertical kiln & $49 \%$ & $7 \%$ \\
& Precalcining kiln & $47 \%$ & $91 \%$ \\
\hline Lime plant & Earth kiln & $70 \%$ & $13 \%$ \\
& Modern kiln & $30 \%$ & $87 \%$ \\
\hline Coke plant & Indigenous coke & $8 \%$ & $0 \%$ \\
& Machine coke & $92 \%$ & $100 \%$ \\
\hline
\end{tabular}

\subsubsection{Nitrogen Oxides $\left(\mathrm{NO}_{\mathrm{x}}\right)$}

Current $\mathrm{NO}_{\mathrm{x}}$ emission control in China only involves power plants and on-road vehicles. By 2005 , only about $46 \%$ of power plants had installed low $\mathrm{NO}_{\mathrm{x}}$ burners (LNB). Considering that all newly-built power plants will use LNB, the application of LNB will increase to $85 \%$ in strategy-[0] by 2020. On 27 January 2010, the Ministry of Environmental Protection of the People's Republic of China (MEP) issued their "Notice of Fossil-Fired Power Plant $\mathrm{NO}_{\mathrm{x}}$ Emission Prevention and Treatment Policy" (the "Notice"). This "Notice" sets the framework for $\mathrm{NO}_{\mathrm{x}}$ reduction actions to be taken under the nation's 12th Five-Year Plan, which begins 1 January 2011. In general, the policy set forth in the "Notice" applies to all coal-fired power plants and co-generation units that are $200 \mathrm{MW}$ or larger, except those in designated "Focus Areas" (areas around Beijing, Shanghai, and Guangdong) where it applies to all units regardless of size. For the units covered by the "Notice", all new, or rebuilt units that have undergone expansion should install low- $\mathrm{NO}_{\mathrm{x}}$ combustion technologies (such as LNB and Over-Fire Air systems) as a first step. For operating units, if the $\mathrm{NO}_{\mathrm{x}}$ emission levels cannot meet the emission standard, then the unit should install flue gas de- $\mathrm{NO}_{\mathrm{x}}$ technology. Major flue gas de- $\mathrm{NO}_{\mathrm{x}}$ technologies mentioned in the "Notice" includes Selective Catalytic Reduction (SCR), Selective Non-Catalytic Reduction (SNCR), and SNCR-SCR systems. Considering the implementation of this "Notice", we assume that in strategy-[1], Chinese government will promote SCR and SNCR installation in new or rebuilt power plants during 2010-2020. In 2020, the application of SCR will reach $30 \%$ under strategy[1]. In strategy-[2], we assume stricter emission standards will be released and all new units will install SCR; therefore, the application ratio of SCR will increase to 55\% in 2020.
Due to the lack of available control technologies, there are no controls on industrial boilers in both strategy-[0] and strategy-[1]. In strategy-[2], we assume that all newly-built industrial boilers will install LNB. The application ratio of LNB will increase to $32 \%$ in 2020.

For the transportation sector, both strategy-[0] and strategy-[1] will follow current mobile sources control policy, while strategy-[2] assumes that starting from 2012, Euro$\mathrm{V}$ will be applied to light-duty cars, Euro-III will be applied to agriculture and construction machines, and Euro-I and Euro-II will be applied to inland water ships.

Cement plants are also an important source of $\mathrm{NO}_{\mathrm{x}}$. Strategy-[0] and strategy-[1] do not consider $\mathrm{NO}_{\mathrm{x}}$ emission control in cement production. Strategy-[2] assumes that SNCR will be applied to those cement plants with the precalcining technique after 2015.

\subsubsection{Particulate Matter (PM)}

In China, the control of particulate matter has achieved noticeable progress. A new, strengthened PM emission standard for power plants was published in 2003 (China standards GB13223-2003). Since then, all new and rebuilt units have to meet the PM emission standard with PM concentrations in flue gas less than $50 \mathrm{mg} \mathrm{m}^{-3}$. As a result, over $92 \%$ of pulverized coal units installed electrostatic precipitators (ESP). In addition, fabric filters have been put into commercial use for the units with a capacity of over $600 \mathrm{MW}$. In future scenarios, the ratio of units with fabric filters will increase to $15 \%$, as shown in Table 3. In addition, all grate boilers using wet scrubbers or cyclones will be phased out or shut down. The percentage of grate boilers will decrease from $3.9 \%$ in 2005 to $1.7 \%$ in 2020.

Currently, industrial boilers either installed wet scrubbers or cyclones to remove PM in the flue gas. In strategy-[0], we assume that new industrial and domestic boilers will be equipped with wet scrubber. Strategy-[1] assumes both new and old boilers will be renovated with wet scrubber. Strategy[2] suggests stricter emission standards, and new industrial and domestic boilers will be equipped with fabric filters and wet scrubbers, respectively.

\subsubsection{Non-methane volatile organic compounds (NMVOC)}

Up to 2009, the existing national legislation to limit NMVOC emissions covered road vehicles (China standards GB/14622, GB/14762, GB/17691, GB/18352, GB/19756), non-road diesel engines (China standard GB/20891), wood paints (China standard GB/18581), indoor decorative paints (China standard GB/18582), adhesives used in shoemaking (China standard GB/19340), and petroleum oil distributions (China standards GB/20950-GB/20952). In this study, strategy[0] and strategy-[1] follow these current NMVOC control legislation. Strategy-[2] assumes further controls on VOC 
Table 5. Penetration of selected NMVOC control technologies in industry and solvents.

\begin{tabular}{|c|c|c|c|c|}
\hline Sector & Sub-sector & Technology & $\begin{array}{r}\text { Removal } \\
\text { efficiency }\end{array}$ & $\begin{array}{r}\text { VOC reduction in } \\
\text { strategy-[2] compared } \\
\text { to that in }[0] /[1]\end{array}$ \\
\hline \multirow[t]{5}{*}{ Industrial process } & Chemical industry & Reduction of vent losses & $70 \%$ & $-21 \%$ \\
\hline & Crude oil refineries & $\begin{array}{l}\text { Inspection and maintenance; } \\
\text { Install vapor recovery units }\end{array}$ & $95 \%$ & $-10 \%$ \\
\hline & Coking plants & End-of-pipe control technology & & $-70 \%$ \\
\hline & Chemical pharmaceutical factory & & $90 \%$ & $-85 \%$ \\
\hline & Vegetable oil Extraction & & & $-29 \%$ \\
\hline \multirow[t]{2}{*}{ Solvent use } & $\begin{array}{l}\text { Ink printing } \\
\text { Paint use }\end{array}$ & $\begin{array}{l}\text { Solvent management and } \\
\text { substitution }\end{array}$ & $50 \%-100 \%$ & $\begin{array}{l}-64 \% \\
-38 \%\end{array}$ \\
\hline & Glues and adhesives & $\begin{array}{l}\text { End-of-pipe technology } \\
\text { applied on new plants }\end{array}$ & $90 \%$ & $-30 \%$ \\
\hline $\begin{array}{l}\text { Fuel transport, storage } \\
\text { and distribution }\end{array}$ & - & Install vapor recovery units & $95 \%$ & $-50 \%$ \\
\hline
\end{tabular}

emissions from solvent use, the chemical industry, and oil refinery plants, as shown in Table 5. The application rate of end-of-pipe treatments for related industries is $40 \%$ in 2020 , which is at a level similar to EGTEI (2008). The removal efficiencies of various measures are given in Table 5 (European Commission, 2001; EGTEI, 2008). Detailed assumptions made during the control policy design period are discussed in Wei (2009) and Wei et al. (2011). With the implementation of these measures, NMVOC emissions under strategy[2] are $10 \%-85 \%$ less compared to that under strategy-[0] and strategy-[1].

\subsubsection{Ammonia $\left(\mathrm{NH}_{3}\right)$}

Although $\mathrm{NH}_{3}$ is one important precursor of inorganic fine particles, $\mathrm{NH}_{3}$ emission control has not received much attention in the current air pollutant control strategy in China. Our previous studies indicated that $\mathrm{NH}_{3}$ emissions have been increasing at an annual growth rate of 3.1\% from 1994 to 2006 (Dong et al., 2010). The potential increase of $\mathrm{NH}_{3}$ emission in the future will enhance the fine particle pollution. In strategy-[0], we project the future $\mathrm{NH}_{3}$ emissions using a logistic method and historical emission data without considering any control in 2020. In strategy-[2], we assume the $\mathrm{NH}_{3}$ emissions will be at same level as that in 2005 .

\subsection{Future emissions estimations}

In this study, we calculated four emission scenarios based on the above energy scenarios and emission control strategies. These emission scenarios are REF[0] (with the REF energy scenario and Strategy-[0]), PC[0] (with the PC energy sce- nario and Strategy-[0]), PC[1] (with the PC energy scenario and Strategy-[1]), and PC[2] (with the PC energy scenario and Strategy-[2]).

The predicted national $\mathrm{SO}_{2}, \mathrm{NO}_{\mathrm{x}}$, and $\mathrm{PM}_{10}$ emissions for different scenarios are given in Fig. 2. Changes in $\mathrm{SO}_{2}, \mathrm{NO}_{\mathrm{x}}$, $\mathrm{PM}_{10}$, NMVOC and $\mathrm{NH}_{3}$ emissions by each province for different scenarios are shown in Fig. 3. The changes for regional emissions for 2020 scenarios are given in Table 6.

\subsubsection{Future $\mathrm{SO}_{2}$ emissions}

The $\mathrm{SO}_{2}$ emissions were $28.6 \mathrm{Tg}$ in 2005. In 2020, $\mathrm{SO}_{2}$ emissions will grow to $33.0 \mathrm{Tg}$ under the REF[0] scenario or decrease to $22.9 \mathrm{Tg}$ under the $\mathrm{PC}[2]$ scenario. $\mathrm{SO}_{2}$ emissions decrease during the period 2005 to 2010 , mainly due to FGD installations in power plants. The REF[0] scenario indicates a rapid increase of $\mathrm{SO}_{2}$ emissions from industrial boilers after 2010. Industrial boilers will replace power plants to become the largest $\mathrm{SO}_{2}$ emission sources. Under the $\mathrm{PC}[2]$ scenario, $\mathrm{SO}_{2}$ emissions from industrial boilers are mainly reduced by the installation of FGD after 2015.

Different control measures have different emission reduction potentials. In PC[2], energy savings and the improvement of energy efficiency will reduce $\mathrm{SO}_{2}$ emissions by 4.1 Tg. Application of low sulfur coal or briquettes in the industrial and domestic sectors will reduce $\mathrm{SO}_{2}$ emissions by $2.9 \mathrm{Tg}$. Installation of FGD in industrial boilers may reduce $\mathrm{SO}_{2}$ emissions by $3.2 \mathrm{Tg}$.

High $\mathrm{SO}_{2}$ emission levels are found in east China including the North China Plain, the Yangtze River Delta (YRD), the Pearl River Delta (PRD), as well as in the Si-chuan basin. Comparing emission levels in 2020 with those in 2005, the 
Table 6. Percentage changes of emission intensity in 2020 among regions and sectors (compared to 2005 level, \%).

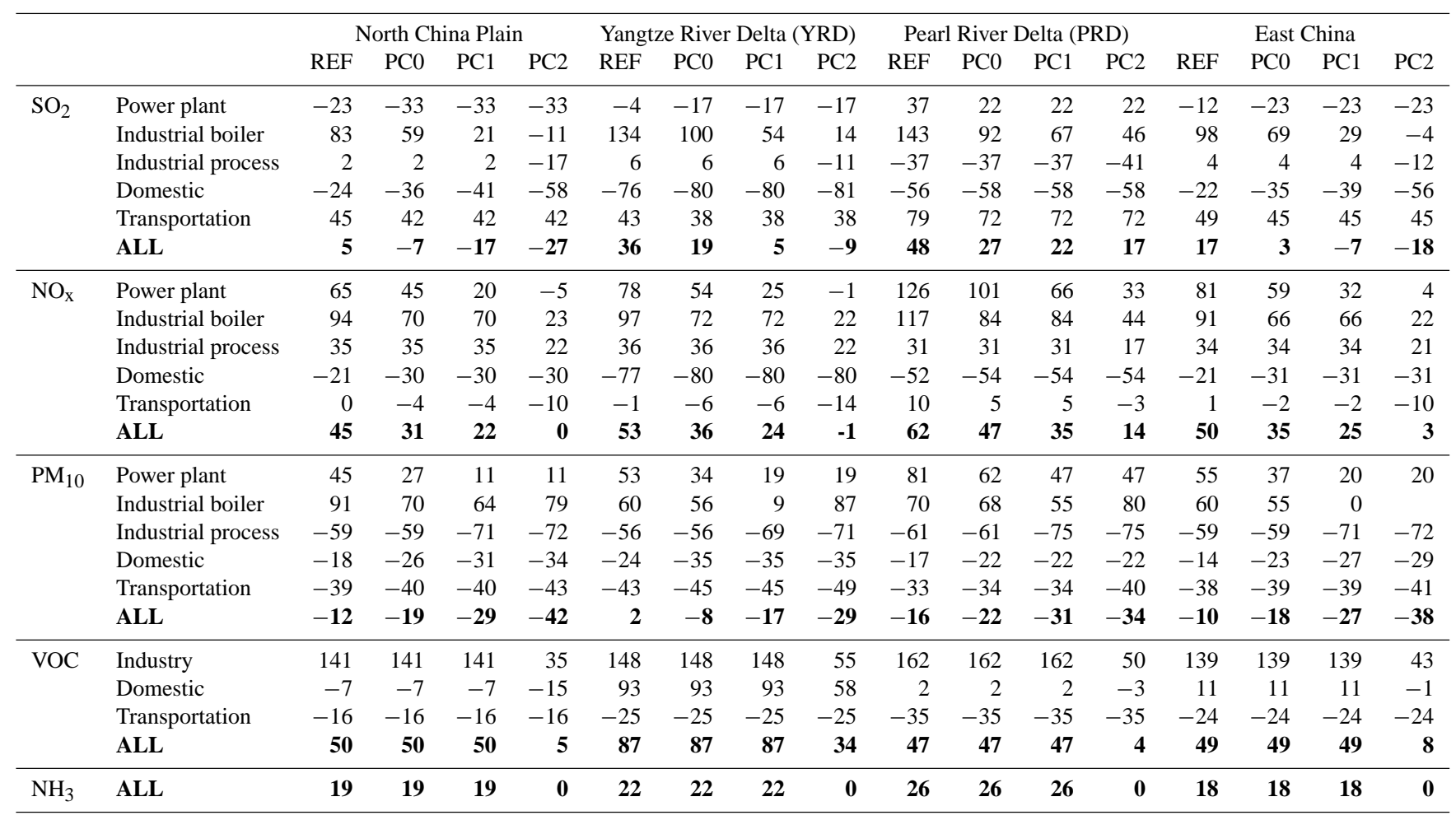

$\mathrm{SO}_{2}$ emissions will increase by $17 \%$ over east China, especially in southeast coastal provinces. Large increases are found in YRD and PRD, by $36 \%$ and $48 \%$ respectively. In $\mathrm{PC}[2]$, the $\mathrm{SO}_{2}$ emissions will decrease by $18 \%$ over east China. However, $\mathrm{SO}_{2}$ emissions in PRD will grow by $17 \%$ even in $\mathrm{PC}[2]$ because of the significant increase in future activities in the PRD area (NDRC, 2008b).

\subsubsection{Future $\mathrm{NO}_{\mathrm{x}}$ emissions}

Compared to those in 2005, the national $\mathrm{NO}_{\mathrm{x}}$ emissions in 2020 will increase $47 \%$ to $26.7 \mathrm{Tg}$ in REF[0]. Even in the strict policy scenario $\mathrm{PC}$ [2], the $\mathrm{NO}_{\mathrm{x}}$ emissions in 2020 will be $18.5 \mathrm{Tg}, 2 \%$ higher than those in 2005. Power plants, industry and transportation are the most important sources of $\mathrm{NO}_{\mathrm{x}}$ emissions, which contributed to $38 \%, 26 \%, 23 \%$, respectively, to $\mathrm{NO}_{\mathrm{x}}$ levels in 2005. In REF[0], $\mathrm{NO}_{\mathrm{x}}$ emissions from power plants, industrial boilers and industrial process will increase by $73 \%, 92 \%$, and $34 \%$ respectively, compared to those in 2005.

Of all the $\mathrm{NO}_{\mathrm{x}}$ control measures in $\mathrm{PC}[2]$, energy savings and the improvement of energy efficiency may reduce $\mathrm{NO}_{\mathrm{x}}$ emissions by $2.6 \mathrm{Tg}$; application of flue gas de-nitration technology in power plants reduce $\mathrm{NO}_{\mathrm{x}}$ emissions by $1.8 \mathrm{Tg}$; Implementation of stricter emission standards for industrial boilers will result in an increase in the installation of LNB and may reduce $\mathrm{NO}_{\mathrm{x}}$ emissions by $3.9 \mathrm{Tg}$.

$\mathrm{NO}_{\mathrm{x}}$ emissions levels are highest in the east coastal regions, such as north China plain, YRD and PRD. In REF[0], the $\mathrm{NO}_{\mathrm{x}}$ emissions in east China are 50\% higher than those in 2005. After effective control measures are applied in $\mathrm{PC}[2], \mathrm{NO}_{\mathrm{x}}$ emissions will remain at 2005 emission levels in national level, while increases are still found in southeast coastal regions, west and northwest China where need strengthened control efforts.

\subsubsection{Future $\mathrm{PM}_{10}$ emissions}

In 2005, the $\mathrm{PM}_{10}$ emissions in China were $17.1 \mathrm{Tg}$. Future $\mathrm{PM}_{10}$ emissions will decrease to $16.0 \mathrm{Tg}$ in REF[0] and 11.1 Tg in PC[2]. Industrial processes and the domestic sectors are the two major sources of $\mathrm{PM}_{10}$ emissions; they contributed $40 \%$ and $30 \%$, respectively, to the total emissions in 2005. Compared to those in 2005, $\mathrm{PM}_{10}$ emissions from industrial processes, transportation, and domestic sources in REF[0] will decrease by $51 \%, 35 \%$, and $11 \%$, respectively, while power plants and industrial boilers will increase by $46 \%$ and $80 \%$. In PC[2], installation of high efficiency dust collectors in industry will reduce $\mathrm{PM}_{10}$ emissions by $0.01 \mathrm{Tg}$ and 5.0 Tg from industrial boilers and industrial processes, respectively, compared to those in 2005 . The reduction of 

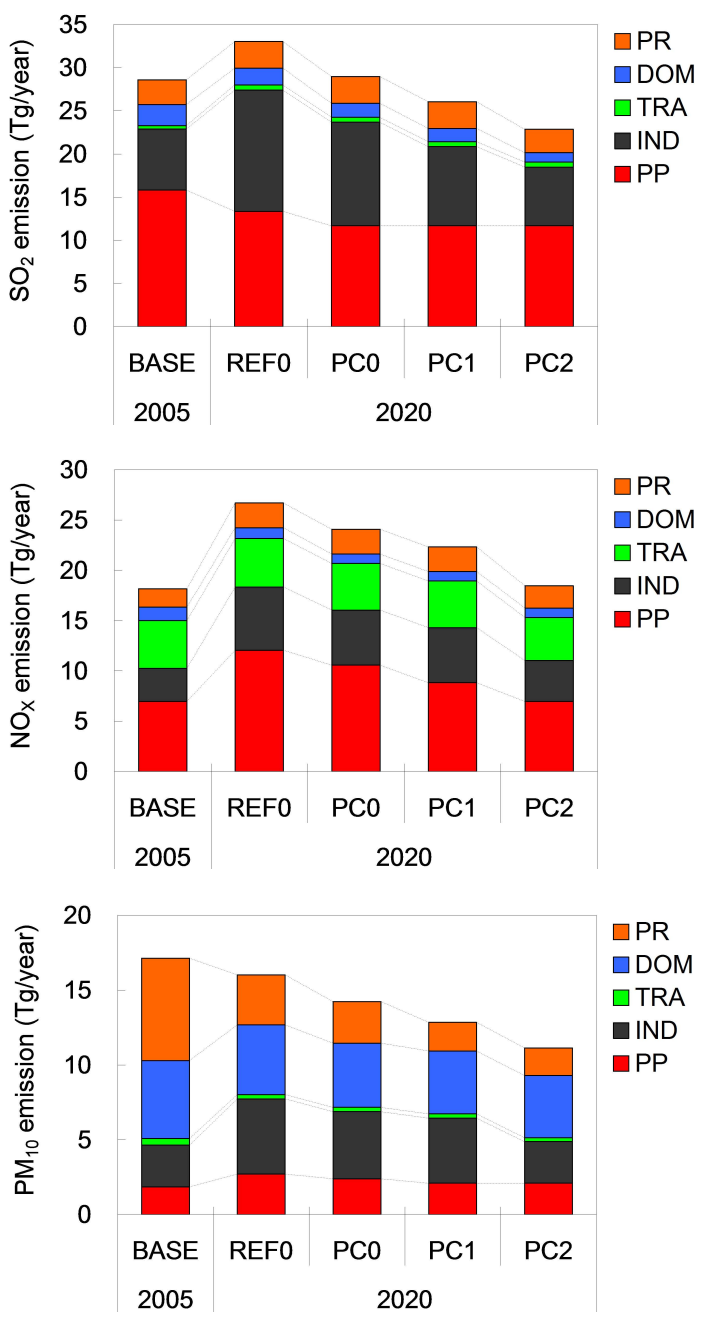

Fig. 2. Contribution of each sector to total emissions in China (PP Power plants; IND - Industry; DOM - Domestic; TRA - Transport; $\mathrm{PR}$ - Industry process). (a) $\mathrm{SO}_{2}$, (b) $\mathrm{NO}_{\mathrm{x}}$, (c) $\mathrm{PM}_{10}$.

$\mathrm{PM}_{10}$ emissions by the installation of high efficiency dust collectors in industrial boilers are almost totally offset by the growth of coal combustion of this sector.

Of all the PM control measures in PC[2], energy saving and the improvement of energy efficiency may reduce $\mathrm{PM}_{10}$ emissions by $1.8 \mathrm{Tg}$; better implementation of emission standards may decrease the $\mathrm{PM}_{10}$ emissions by $1.4 \mathrm{Tg}$; Application of high efficiency dust collectors in industry may reduce $\mathrm{PM}_{10}$ emissions by $1.7 \mathrm{Tg}$.

High $\mathrm{PM}_{10}$ emissions are found in east China, including north China plain, YRD and PRD. But their emissions will be well controlled in both two 2020 scenarios. The $\mathrm{PM}_{10}$ emissions over east China will decrease by $-10 \%$ and $-38 \%$ in $\mathrm{REF}[0]$ and $\mathrm{PC}[2]$, respectively.

\subsubsection{Future NMVOC emissions}

The NMVOC emissions were $19.4 \mathrm{Tg}$ in 2005 . Future NMVOC emissions in China are predicted to be $26.5 \mathrm{Tg}$ in REF[0] and 19.9 Tg in PC[2]. The control efforts applied in $\mathrm{PC}[2]$ will contribute to a $25 \%$ reductions of NMVOC emissions. Compared to those in 2005, the NMVOC emissions over east China will increase by $49 \%$ and $8 \%$ in REF[0] and $\mathrm{PC}[2]$, respectively.

\subsubsection{Future $\mathrm{NH}_{3}$ emissions}

$\mathrm{NH}_{3}$ emissions in China were $16.6 \mathrm{Tg}$ in 2005. Future $\mathrm{NH}_{3}$ emissions in China are predicted to be $19.3 \mathrm{Tg}$ in $2020,16 \%$ higher than those in 2005. Livestock and fertilizer applications are two major contributors, which account for over $90 \%$ of total $\mathrm{NH}_{3}$ emissions. Predicted of $\mathrm{NH}_{3}$ emissions indicate an increase in east coastal regions such as north China plain, YRD and PRD in 2020. The $\mathrm{NH}_{3}$ emissions over east China will increase by $18 \%$ over east China, in $\mathrm{REF}[0] . \mathrm{NH}_{3}$ emissions will remain the same in 2020 as those in 2005, in PC[2].

\section{Impacts of emission changes on future air quality}

\subsection{Air quality modeling system}

The CMAQ model, which was developed by US EPA (Byun and Ching, 1999; Binkowski and Roselle, 2003), has been extensively evaluated by several modeling studies in Asia (Zhang et al., 2006; Streets et al., 2007; Uno et al., 2007; Fu et al, 2008; Li et al., 2008). CMAQ version 4.7 is applied in this study to simulate the air quality in China for the 2005 baseline and for the 2020 scenarios. The modeling domain covers most of China with a $36 \times 36 \mathrm{~km}$ grid resolution and with nested simulations at $12-\mathrm{km}$ over eastern China, as shown in Fig. 4. A Lambert projection with the two true latitudes of $25^{\circ} \mathrm{N}$ and $40^{\circ} \mathrm{N}$ is used. The domain origin is $34^{\circ} \mathrm{N}, 110^{\circ} \mathrm{E}$. The coordinates of the bottom left corner are $(x=-2934 \mathrm{~km}, y=-1728 \mathrm{~km})$. The vertical resolution of CMAQ includes fourteen layers from the surface to the tropopause with denser layers at lower altitudes to resolve the planetary boundary layer (PBL). The Carbon Bond Mechanism (CB05) with aqueous and aerosol extensions and the AREO5 aerosol mechanism are chosen for the gas-phase chemistry and aerosol modules, respectively. A spin-up period of seven days is used for model simulations to reduce the influence of initial conditions on model results. The boundary conditions are based on nesting from the global chemical transport model GEOS-Chem (http://acmg.seas.harvard.edu/geos/).

The fifth-generation National Center for Atmospheric Research (NCAR)/Pennsylvania State University (PSU) Mesoscale Model (MM5), version 3.7, is applied to generate the meteorological fields needed for CMAQ simulations. In the MM5 simulations, 23 sigma levels are selected for 


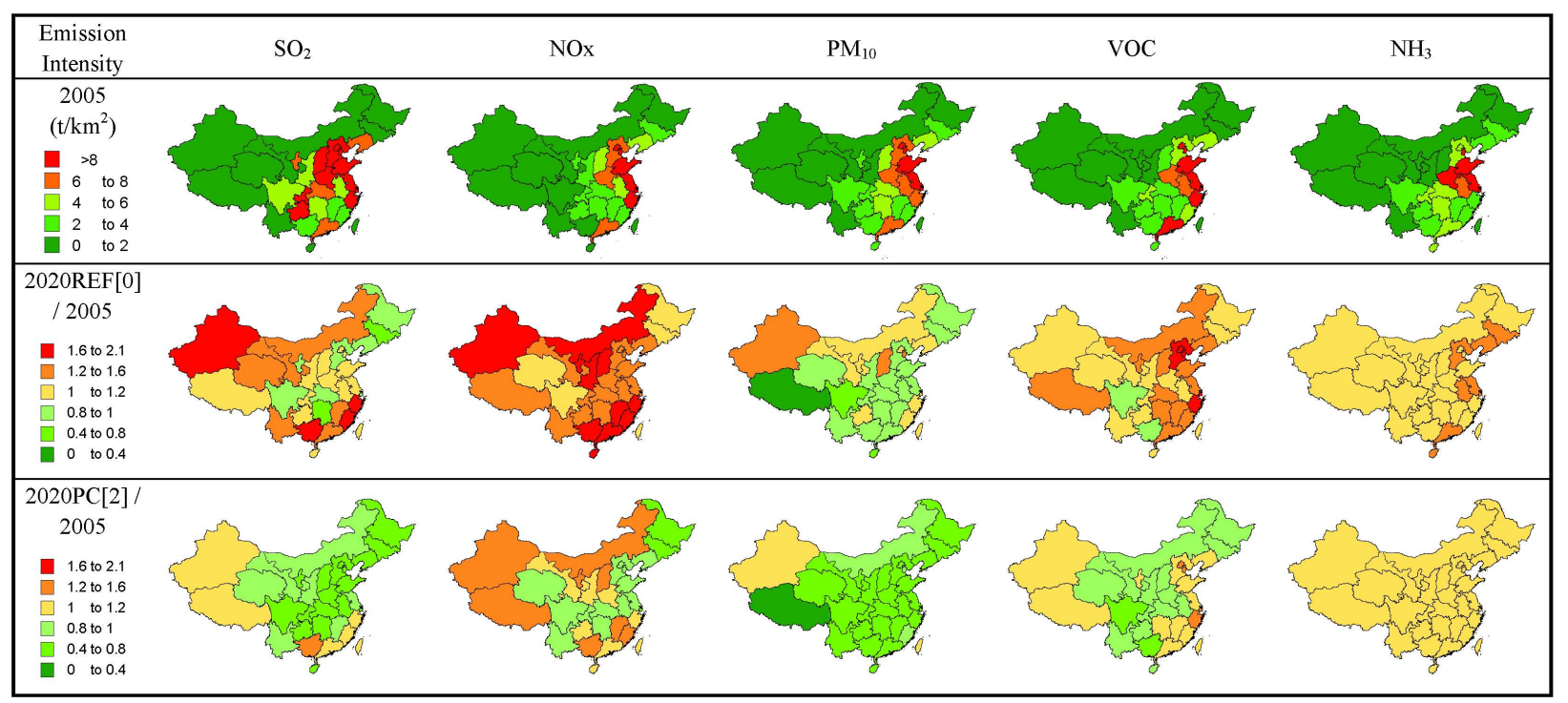

Fig. 3. Emission intensities of air pollutants in 2005 and 2020.

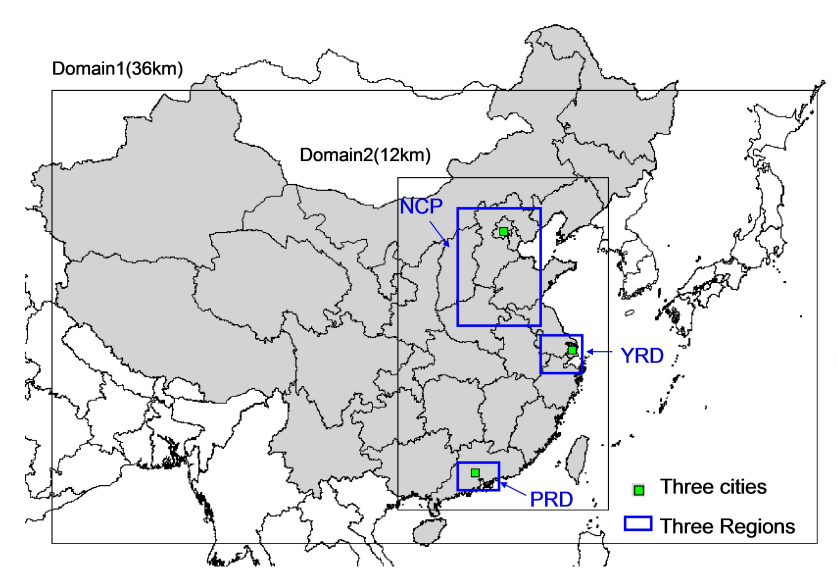

Fig. 4. Modeling domain and location of three regions.

the vertical grid structure with the model's top pressure of $100 \mathrm{mb}$ at approximately $15 \mathrm{~km}$. The height of the first 12 levels extends up to $2 \mathrm{~km}$ from the surface with the lowest level at approximately $40 \mathrm{~m}$. The MM5 data sources and major physics options are the same as described in our previous paper (Wang et al., 2010). The Meteorology-Chemistry Interface Processor (MCIP) version 3.4 is applied to process the meteorological data in a format required by CMAQ.

The CMAQ simulations of the base year emission inventory were compared and validated with satellite and surface observation data, as given by Xing et al. (2010). Generally, the model reproduces both spatial distribution and seasonal variation of tropospheric $\mathrm{NO}_{2}$ and $\mathrm{SO}_{2}$ column densities and Aerosol Optical Depth (AOD) in China that have been observed by OMI (Ozone Measurement Instrument), SCIAMACHY (Scanning Imaging Absorption SpectroMe- ter for Atmospheric Cartography), and MODIS (Moderate Resolution Imaging Spectroradiometer). Surface concentrations of $\mathrm{NO}_{2}, \mathrm{SO}_{2}$, and $\mathrm{PM}_{10}$ given by CMAQ model are also comparable with those observed in Beijing, Shanghai, and Guangzhou. The results suggest that the anthropogenic emissions of $\mathrm{SO}_{2}, \mathrm{NO}_{\mathrm{x}}$, and $\mathrm{PM}_{10}$ used in this study are in line with both satellite and ground observations therefore are of acceptable accuracy. The performances of CMAQ simulation on ozone concentration with the same emission inventories have been validated by Li et al. (2008) for Yangtze River Delta, and Wang et al. (2010) for Beijing in July and August 2008. However, there is overestimation $\mathrm{SO}_{2}$ and underestimation for $\mathrm{PM}_{10}$ in some industry-intensive areas because of the inaccuracy of temporal allocations. CMAQ model also significantly underestimates $\mathrm{PM}_{2.5}$ concentration in Beijing, mainly due to the underestimation of OC and EC. The absolute emission amounts may suffer from some uncertainties. So this study mainly focused on the impacts from the future emission trend which is driven by the development of future economy as well as the pace of control strategy.

Air quality impacts from emission changes for all species are calculated using the above MM5/CMAQ modeling system. The 2005 baseline scenario and two future scenarios (i.e., high-emission scenario REF[0] and low-emission scenario $\mathrm{PC}[2])$ has been simulated. The simulated surface concentration of $\mathrm{SO}_{2}, \mathrm{NO}_{2}, 1$-h maxima $\mathrm{O}_{3}, \mathrm{PM}_{2.5}, \mathrm{SO}_{4}^{2-}$, $\mathrm{NO}_{3}^{-}$and total sulfur/nitrogen deposition in 2005 baseline scenario, as well as their changes in two future scenarios are given in Figs. 5, 6.

Besides, in order to explore the control benefit from each pollutant control, we have conducted 10 additional scenarios, where one pollutant is set to the two future scenario level (i.e., REF[0] and PC[2]) and the rest are held at the 2005 


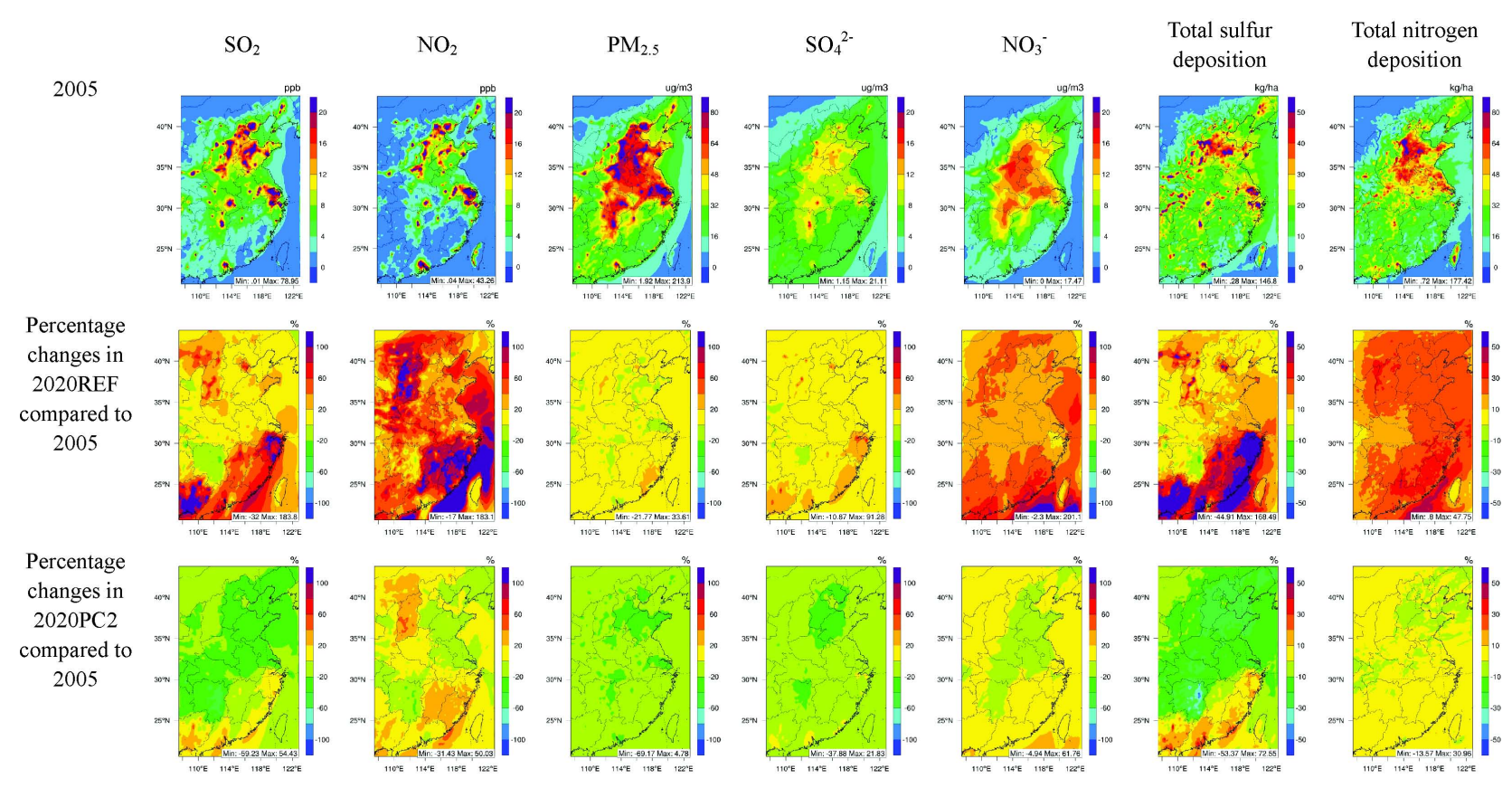

Fig. 5. Spatial changes of $\mathrm{SO}_{2}, \mathrm{NO}_{2}, \mathrm{PM}_{2.5}$ concentration and total sulfur and nitrogen deposition in 2020 (4-month mean).

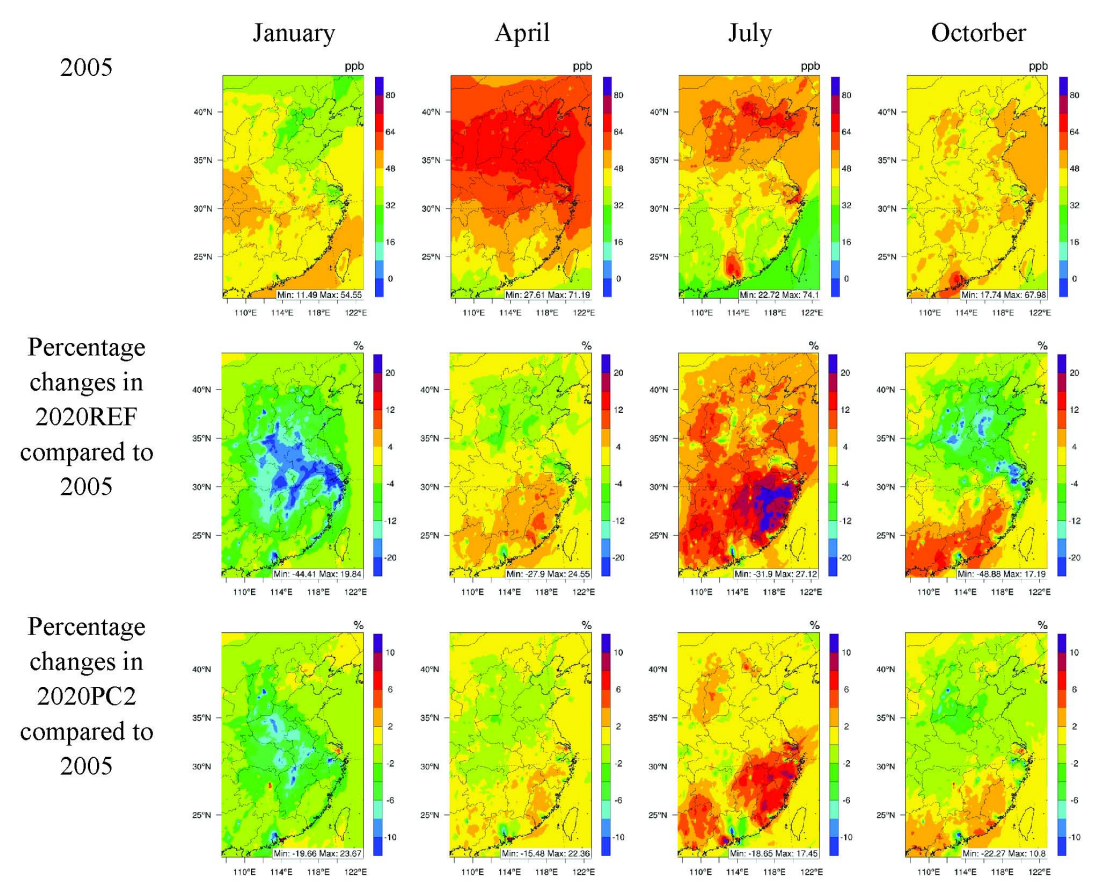

Fig. 6. Spatial changes of $\mathrm{O}_{3}$ in 2020 (monthly mean of daily 1-h maxima).

level. The individual impacts of $\mathrm{SO}_{2}, \mathrm{NO}_{\mathrm{x}}, \mathrm{NH}_{3}, \mathrm{NMVOC}$ and primary $\mathrm{PM}$ emission changes have been analyzed using that sensitivity analysis for three fast-developing city clusters (i.e., north China plain, YRD and PRD), as seen in Figs. 7, 8 and 9 . The air quality responses are defined as the percent change in 2020 scenarios relative to the 2005 scenario, at average regional level.

\subsection{Surface concentrations of $\mathrm{SO}_{2}$ and $\mathrm{NO}_{2}$}

Following the continual increase of $\mathrm{SO}_{2}$ and $\mathrm{NO}_{\mathrm{x}}$ emissions in REF[0], compared to that in 2005, the $\mathrm{SO}_{2}$ and $\mathrm{NO}_{2}$ concentration will increase in most of areas (averagely by $28 \%$ and $41 \%$ domainwide), particularly higher in southeast coastal provinces, north west China which have large 
$\mathrm{SO}_{2}$

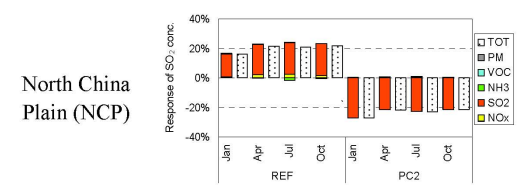

Yangtze
River Delta
(YRD)
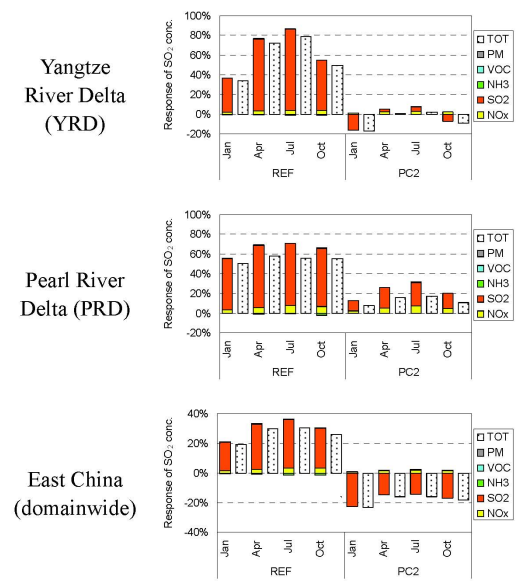

$\mathrm{NO}_{2}$
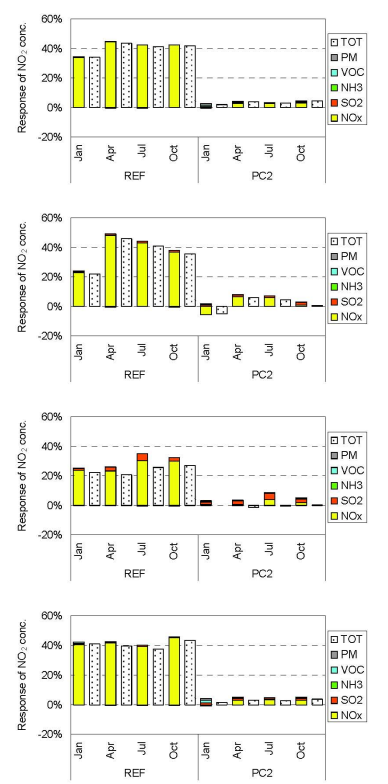

$\mathrm{O}_{3}$
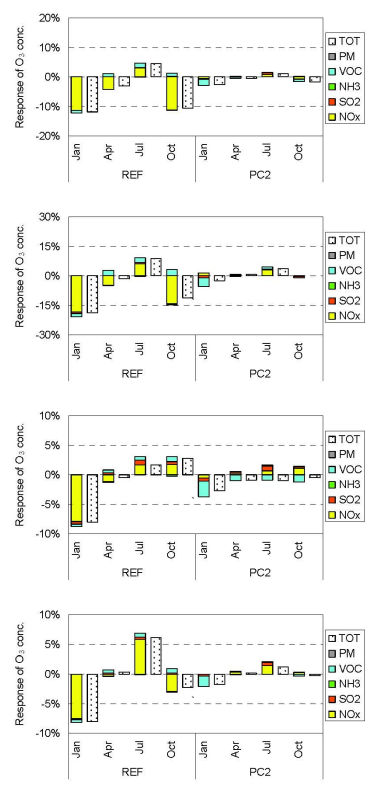

Fig. 7. Percentage changes of surface concentration of gas species relative to the 2005 scenarios in 2020 (monthly average for $\mathrm{SO}_{2}$ and $\mathrm{NO}_{2}$, monthly mean of daily 1-h maxima for $\mathrm{O}_{3}$; TOT represent the differences between two future scenario with 2005 baseline, $\mathrm{PM}$, VOC, $\mathrm{NH}$, $\mathrm{SO}_{2}, \mathrm{NO}_{\mathrm{x}}$ represent the individual impacts of their emission changes in 2020).

increase of energy use in industrial boilers and transportation. The effects of control measures can be seen from the reduction of $\mathrm{SO}_{2}$ and $\mathrm{NO}_{2}$ concentration in $\mathrm{PC}$ [2]. In $\mathrm{PC}[2]$, the $\mathrm{SO}_{2}$ concentrations in 2020 will decrease by $18 \%$ domainwide compared to that in 2005. As indicated in Sect. 2.3.2, China realized the rapid $\mathrm{NO}_{\mathrm{x}}$ emissions in last 10 years and started to control its $\mathrm{NO}_{\mathrm{x}}$ emissions in 2010. During 2010-2020, the control measures in $\mathrm{PC}$ [2] will reduce $30 \%$ of $\mathrm{NO}_{\mathrm{x}}$ emissions. As a consequence, the $\mathrm{NO}_{2}$ concentrations in 2020 in most of areas over east China are same as those in 2005. But slight increases are found in southeast coastal provinces. More strengthen policy should be conducted focused on those area.

Concentrations of $\mathrm{SO}_{2}$ and $\mathrm{NO}_{2}$ are mainly affected by their primary emissions, as shown in Fig. 7, which indicates that control of the relative primary emissions is an effective way to reduce these two pollutants.

\subsection{Surface ozone concentration}

The ozone concentrations have strong seasonal variations. Ozone concentration is higher in April and July for most of areas over east China. Besides, higher ozone concentration also appears in October in PRD. Due to the growth of $\mathrm{NO}_{\mathrm{x}}$ and VOC emissions in REF[0], ozone concentrations in most of areas over east China increase significantly in July. Besides, ozone concentrations in south China also increase in April and October. In July, the combined effects of $\mathrm{NO}_{\mathrm{x}}$ and VOC emission growth on ozone concentrations are $8 \%$ domain-wide, compared to that in 2005.
Because of the titration reaction of $\mathrm{NO}$ to $\mathrm{NO}_{2}$ and the VOC-limited regime (excess $\mathrm{NO}_{2}$ consumes $\mathrm{OH}$ to generate $\mathrm{HNO}_{3}$ ), ozone concentrations decrease significantly in January for all areas and in April and October for north China and megacities (e.g., Guangzhou), see Figs. 6, 7. These results suggest that the effects of different ozone chemistry regimes in different seasons should be considered during $\mathrm{NO}_{\mathrm{x}}$ control policy-making. It is better to strictly control $\mathrm{NO}_{\mathrm{x}}$ emissions in summer (in summer and fall for PRD) to obtain maximal ozone reduction benefits.

\subsection{Surface concentration of particulate matter}

The future $\mathrm{PM}_{2.5}$ concentrations are significantly affected by the changes of its precursor emissions (i.e., $\mathrm{SO}_{2}, \mathrm{NO}_{\mathrm{x}}, \mathrm{NH}_{3}$, NMVOC and PM). In REF[0], the $\mathrm{PM}_{2.5}$ concentration in 2020 will slightly increase by $8 \%$ domainwide mainly because of the growth of $\mathrm{SO}_{2}, \mathrm{NO}_{\mathrm{x}}$ and $\mathrm{NH}_{3}$ emissions, especially in April, July and October. Reduction of primary $\mathrm{PM}$ emission can compensate some increases of $\mathrm{PM}_{2.5}$ concentration. Based on the stepped reductions from REF[0] to $\mathrm{PC}$ [2], the $\mathrm{PM}_{2.5}$ concentration will decrease by $16 \%$ domainwide. Reduction of primary PM emissions plays the most important role in the decrease over east China, see Fig. 8.

Because of the increase of $\mathrm{SO}_{2}$ emissions in REF[0], sulfate concentrations in 2020 increase by $7 \%$ domainwide. In PC[2], stricter controls of $\mathrm{SO}_{2}$ emissions reduce sulfate concentration in 2020 by $14 \%$ domainwide, while sulfate concentration in PRD slightly increases $9 \%$ because of the 

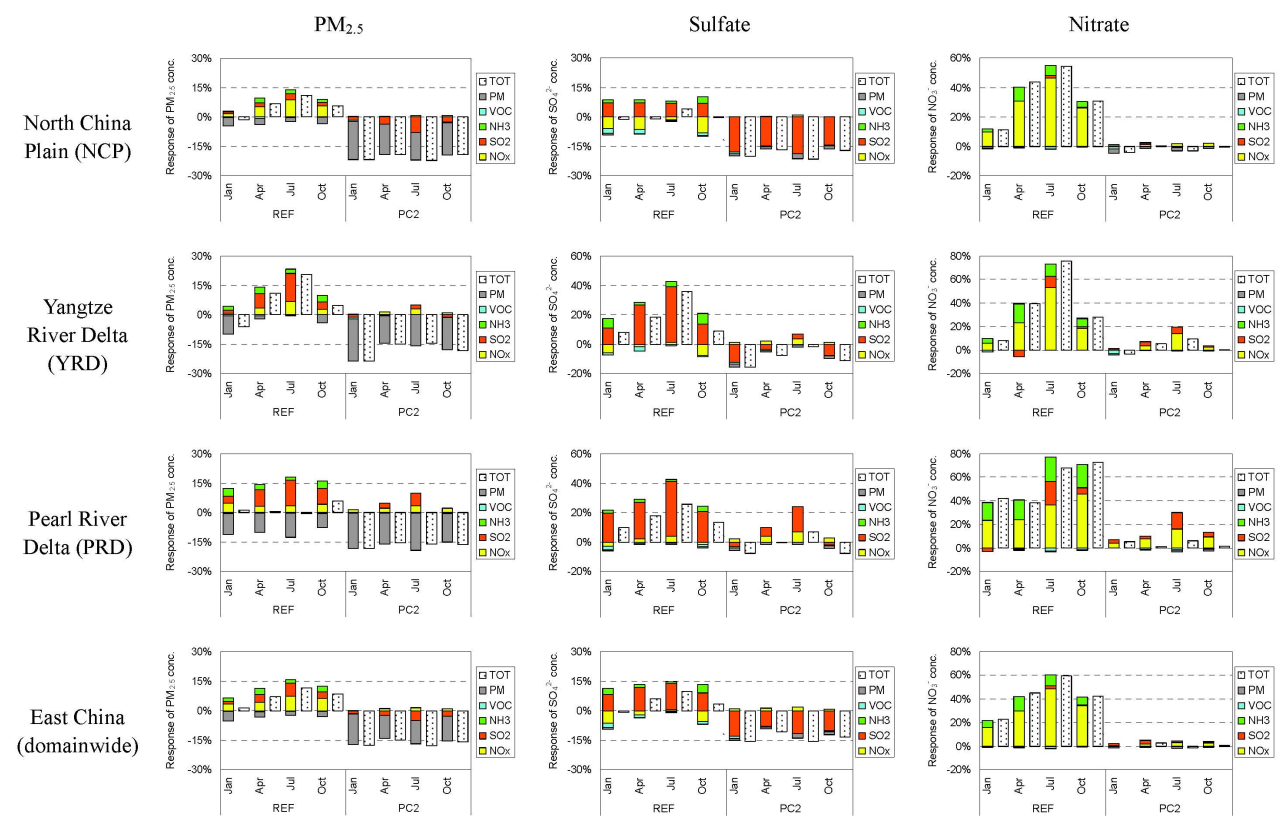

Fig. 8. Percentage changes of surface PM concentrations relative to the 2005 scenarios in 2020 (monthly average; TOT represent the differences between two future scenario with 2005 baseline, $\mathrm{PM}, \mathrm{VOC}, \mathrm{NH}_{3}, \mathrm{SO}_{2}, \mathrm{NO}_{\mathrm{x}}$ represent the individual impacts of their emission changes in 2020).

increase of $\mathrm{SO}_{2}$ emissions caused by the sharply growth of future activities. The growth of $\mathrm{NO}_{\mathrm{x}}$ emissions has positive impacts on the sulfate reduction because of the ozone chemistry, especially in January, April and October when VOClimited regimes are dominating. Extra $\mathrm{NO}_{\mathrm{x}}$ emission will react with $\mathrm{OH}$ to obstruct its reaction with $\mathrm{SO}_{2}$ to generate sulfate. Growth of $\mathrm{NH}_{3}$ emissions contributes to a $3 \%$ increase in sulfate domainwide. It was reported that when $\mathrm{pH}$ is over 5 , the reduction of $50 \% \mathrm{NH}_{3}$ emissions produced a decrease of the cloud $\mathrm{pH}$ which leads to a decrease of in-cloud production of $\mathrm{SO}_{4}^{2-}$. In contrast, the growth of $\mathrm{NH}_{3}$ emissions will increase $\mathrm{pH}$ which results in production of more $\mathrm{SO}_{4}^{2-}$ (Tsimpidi et al., 2007; Makar et al., 2009).

In REF[0], the growth of emissions will increase the nitrate concentration in 2020 by $40 \%$ domainwide, especially in April and July when atmospheric oxidization is strong and the biogenic VOC emission is large. $\mathrm{NO}_{\mathrm{x}}$ emissions are the dominate contributor, and the growth of $\mathrm{NH}_{3}$ and $\mathrm{SO}_{2}$ emissions also contributes to some increases of nitrate concentration caused by the thermodynamic effect (Tsimpidi et al., 2007). In PC[2], which applies stricter controls on $\mathrm{NO}_{\mathrm{x}}$ emissions, the nitrate concentration will be kept as the same level as 2005 over China, though slight increase shown in YRD and PRD.

\subsection{Total sulfur deposition and nitrogen deposition}

In this paper, the total sulfur deposition is defined as the wet and dry deposition of $\mathrm{SO}_{4}^{2-}$ and $\mathrm{SO}_{2}$ (all counted by Sulfur); the total nitrogen deposition is defined as wet and dry deposition of $\mathrm{NO}_{3}^{-}, \mathrm{HNO}_{3}, \mathrm{NH}_{3}, \mathrm{~N}_{2} \mathrm{O}_{5}, \mathrm{NO}, \mathrm{NO}_{2}$, peroxyacetyl nitrate (PAN), HONO, organic nitrate (NTR) (all counted by Nitrogen).

Because of the increase of $\mathrm{SO}_{2}$ emissions in REF[0], total sulfur deposition in 2020 will increase by $19 \%$ domainwide, especially higher in YRD and PRD. In PC[2], compared to that in 2005, stricter controls on $\mathrm{SO}_{2}$ emission will reduce the total sulfur deposition by $15 \%$ domainwide, see Fig. 9 .

Both $\mathrm{NO}_{\mathrm{x}}$ and $\mathrm{NH}_{3}$ emissions have large impacts on the total nitrogen deposition, see Fig. 9. In REF[0], the total nitrogen deposition will increase by $25 \%$ domainwide. In $\mathrm{PC}$ [2], which stricter controls on $\mathrm{NO}_{\mathrm{x}}$ emissions are applied and $\mathrm{NH}_{3}$ emissions are kept as 2005 level, the total nitrogen deposition will only present slightly increases by $2 \%$ domainwide.

\section{Conclusions}

Because of the rapid growth of the economy and population, China's energy consumption by power plants and industries is predicted to double, and on-road transport is expected to be triple by 2020. Improvement of air quality is a big challenge that China is facing. It's urgent for the government to find possible solutions to reduce the primary emissions in order to protect human health and the ecosystem.

Based on current control legislation and proposed control (as in REF[0]), the emission of $\mathrm{SO}_{2}, \mathrm{NO}_{\mathrm{x}}$, VOC and $\mathrm{NH}_{3}$ 


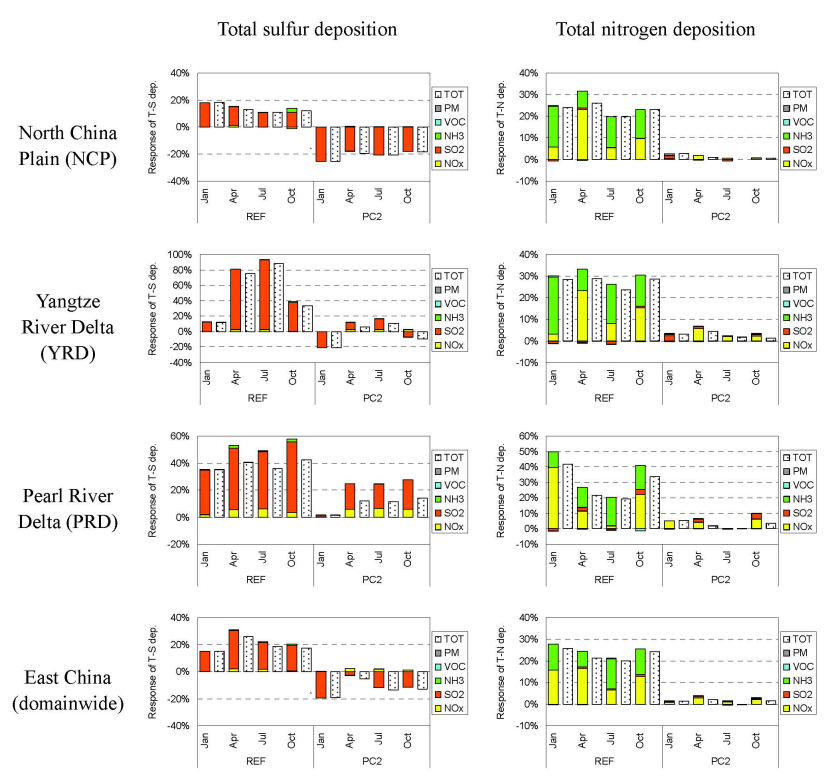

Fig. 9. Percentage changes of total $\mathrm{S} / \mathrm{N}$-deposition relative to the 2005 scenarios in 2020 (monthly total; TOT represent the differences between two future scenario with 2005 baseline, PM, VOC, $\mathrm{NH}_{3}, \mathrm{SO}_{2}, \mathrm{NO}_{\mathrm{x}}$ represent the individual impacts of their emission changes in 2020).

will increase by $17 \%, 50 \%, 49 \%$ and $18 \%$, respectively, in 2020, while PM will be reduced by $10 \%$ over East China, compared to those in 2005. That will lead to a significant impact on air quality. CMAQ simulations indicate that the concentration of $\mathrm{SO}_{2}$ and $\mathrm{NO}_{2}$ will increase by $28 \%$ and $41 \%$ domainwide in annual mean level. The daily 1-h maximum concentration of ozone in summer will increase by $8 \%$. The concentration of sulfate and nitrate will increase by $7 \%$ and $40 \%$. In addition, total sulfur and nitrogen depositions are predicted to increase by $19 \%$ and $25 \%$, respectively.

A detailed step-by-step control implementation plan has been designed in this study. If a more sustainable energy development strategy is adopted to improve the energy efficiency, the emissions of $\mathrm{SO}_{2}, \mathrm{NO}_{\mathrm{x}}$ and $\mathrm{PM}_{10}$ will be reduced by $4.1 \mathrm{Tg}, 2.6 \mathrm{Tg}$, and $1.8 \mathrm{Tg}$, respectively. If current control policies is well implemented and the pollution sources can meet the emission standard, $\mathrm{SO}_{2}, \mathrm{NO}_{\mathrm{x}}$ and $\mathrm{PM}_{10}$ emissions will be reduced by $2.9 \mathrm{Tg}, 1.8 \mathrm{Tg}$, and $1.4 \mathrm{Tg}$, respectively. Furthermore, if stricter policy standards are adopted to promote the applications of advanced control technologies, the $\mathrm{SO}_{2}, \mathrm{NO}_{\mathrm{x}}$ and $\mathrm{PM}_{10}$ emissions will be reduced by $3.2 \mathrm{Tg}$, $3.9 \mathrm{Tg}$, and $1.7 \mathrm{Tg}$, respectively.

In the strict emission control scenario (PC[2]), the $\mathrm{SO}_{2}$ and $\mathrm{PM}_{10}$ emissions will decrease by $18 \%$ and $38 \%$, compared to those in 2005, while the $\mathrm{NO}_{\mathrm{x}}$ and VOC emissions will increase by $3 \%$ and $8 \%$, respectively. $\mathrm{NH}_{3}$ emissions are kept at same level as those in 2005. After all the substantial emission controls, the future air quality is able to maintain as 2005 level, over East China, while the southeast coastal provinces and inter-Mongolia and Shanxi, need more strengthened control actions on the $\mathrm{SO}_{2}$ and $\mathrm{NO}_{\mathrm{x}}$ emisssoin in industry boiler and transportation.

While $\mathrm{NH}_{3}$ has not been considered in the current air pollutant control strategy in China, its impact on $\mathrm{PM}_{2.5}$ concentrations is important. In addition, $\mathrm{NH}_{3}$ emissions have significant impacts on total nitrogen deposition in the future. $\mathrm{NH}_{3}$ emission controls should be considered as well.

There are several limitations in this study. First, the absolute values in this study suffer the uncertainties in the emissions, e.g., previous studies indicate that the uncertainties (i.e., 95\% confidence intervals around the central estimates) in our base year emissions are from $-14 \%$ to $12 \%\left(\mathrm{SO}_{2}\right)$, from $-10 \%$ to $36 \%\left(\mathrm{NO}_{\mathrm{x}}\right)$, from $-44 \%$ to $109 \%$ (NMVOC), and from $-12 \%$ to $42 \%\left(\mathrm{PM}_{10}\right)$, respectively (Wei et al., 2008; Zhao et al., 2011). These uncertainties pose more difficulties for the accurate forecast of future air quality in China. Secondly, the model biases may affect the results of future projections on air quality. For example, the limitation of SOA formation mechanism used in the model may underestimate the impact from the future growth of VOC emissions, which is considered as another important species to fine particles (Xing et al., 2010). However, this study aims to project the relative changes of future emissions according to the development of future economy as well as the pace of control strategy and the potential impacts of future emission on regional air quality in China. Therefore the results can provide important reference for the air pollution control policy-making.

Acknowledgements. This study is financially supported by Natural Science Foundation of China (20921140095 and 20921140409), National High Technology Research and Development Program of China (2006AA06A309), and Toyota Motor Corporation The authors thank to Ke-Jun Jiang and Yi-Xiang Deng from Energy Research Institute of China for their help on energy projection; Carey Jang from US EPA and Yun Zhu from South China University of Technology for their help on air quality modeling; Jerry Davis from US EPA/NCSU for his help in editing.

Edited by: C. K. Chan

\section{References}

Amann, M., Jiang, K. J., Hao, J. M., Wang, S. X., Zhuang, X., Wei, W., Deng, Y. X., Liu., H., Xing, J., Zhang, C. Y., Bertok, I., Borken, J., Cofala, J., Heyes, C., Höglund, L., Klimont, Z., Purohit, P., Rafaj, P., Schöpp, W., Toth, G., Wagner, F., and Winiwarter, W.: GAINS-Asia: Scenarios for costeffective control of air pollution and greenhouse gases in China. International Institute for Applied Systems Analysis (IIASA), Laxenburg, Austria, available at: http:/gains.iiasa.ac.at/gains/ download/GAINS-Asia-China.pdf (last access: 6 November 2010), 2008

Binkowski, F. S. and Roselle, S. J.: Models-3 Community Multiscale Air Quality (CMAQ) Model aerosol compo- 
nent, 1. Model description, J. Geophys. Res., 108, 4183, doi:10.1029/2001JD001409, 2003.

Byun, D. W. and Ching J. K. S.: Science algorithms of the EPA Models-3 community multiscale air quality (CMAQ) modeling system, Natl. Exposure Res. Lab, Research Triangle Park, NC, 1999.

CLA (China Lime Association), Report on Chinese lime industry development in the first half of 2005, 2005 (in Chinese).

Dentener, F., Stevenson, D., Ellingsen, K., Van Noije, T., Schultz, M. G., Amann, M., Atherton, C., Bell, N., Bergmann, D., Bey, I., Bouwman, L., Butler, T., Cofala, J., Collins, B., Drevet, J., Doherty, R., Eickhout, B., Eskes, H., Fiore, A. M., Gauss, M., Hauglustaine, D., Horowitz, L., Isaksen, I. S. A, Josse, B., Lawrence, M., Krol, M., Lamarque, J. F., Montanaro, V., Müller, J. F., Peuch, V. H., Pitari, G., Pyle, J., Rast, S., Rodriguez, J., Sanderson, M., Savage, N. H., Shindell, D., Strahan, S., Szopa, S., Sudo, K., Van Dingenen, R., Wild, O., and Zeng, G.: The global atmospheric environment for the next generation, Environ. Sci. Technol., 40, 3586-3594, 2006.

Dickerson, R. R., Li, C., Li, Z., Marufu, L. T., Stehr, J. W., McClure, B., Krotkov, N., Chen, H., Wang, P., Xia, X., Ban, X., Gong, F., Yuan, J., and Yang, J.: Aircraft observations of dust and pollutants over northeast China: Insight into the meteorological mechanisms of transport, J. Geophys. Res., 112, D24S90, doi:10.1029/2007JD008999, 2007.

Dong, W. X., Xing, J., and Wang, S. X.: Temporal and Spatial Distribution of Anthropogenic Ammonia Emissions in C.hina: 1994-2006, Chinese J. Environ. Sci., 31(7), 1457-1463, 2010.

EGTEI: Protocol to abate acidification, eutrophication and groundlevel ozone, available at: http://www.citepa.org/forums/egtei/ egtei_index.htm (last access: November 2010), 2008.

European Commission: Clean air for Europe (CAFÉ) programme, available at: http://europa.eu/legislation_summaries/ environment/air_pollution/128026_en.htm (last access: November 2010), 2001.

Fu, J. S., Jang, C. J., Streets, D. G., Li, Z., Kwok, R., Park, R., and Hang, Z.: MICS-Asia II: evaluating gaseous pollutants in East Asia using an advanced modeling system: Models-3/CMAQ System, Atmos. Environ., 42(15), 3571-3583 doi:10.1016/j. atmosenv.2007.07.058, 2008

He, K.-B., Huo, H., Zhang, Q., He, D.-Q., An, F., Wang, M., and Walsh, M. P.: Oil consumption and $\mathrm{CO}_{2}$ emission in China's road transport: current status, future trends, and policy implications, Energy Policy, 33(12), 1499-1507, 2005.

IEA (International energy agency): World energy outlook 2007, Paris, 2007.

Jiang, K.-J. and Hu, X.-L.: Energy demand and emissions in 2030 in China: scenarios and policy options, Environmental Economics and Policy Studies, 7(3), 233-250, 2006.

Jiang, K.-J., Hu, X.-L., Zhuang, X., and Liu, Q.: China's Lowcarbon Scenarios and Roadmap for 2050, Sino-Global Energy, 14(6), 1-7, 2009 (in Chinese).

Klimont, Z., Cofala, J., Schöpp, W., Amann., M., Streets, D. G., Ichikawa, Y., and Fujita., S.: Projections of $\mathrm{SO}_{2}, \mathrm{NO}_{\mathrm{x}}, \mathrm{NH}_{3}$ and VOC emissions in East Asia up to 2030, Water Air Soil Pollut., 130, 193-198, 2001.

Klimont, Z., Cofala, J., Xing, J., Wei, W., Zhang, C., Wang S., Jiang, K., Bhandari, P., Mathur, R., Purohit, P., Rafaj, P., Chambers, A., Amann, M. and Hao, J.: Projections of $\mathrm{SO}_{2}, \mathrm{NO}_{\mathrm{x}}$ and carbonaceous aerosols emissions in Asia, Tellus B, 61, 602-617, 2009.

Lei, Y., He, K. B., Zhang, Q., and Liu, Z. Y.: Technology-Based Emission Inventory of Particulate Matters (PM) from Cement Industry, Chinese Journal of Environmental Science, 29, 23662371, 2008.

Liang, Q., Jaegl'e, L., Jaffe, D. A., Weiss-Penzias, P., Heckman, A., and Snow, J. A.: Long-range transport of Asian pollution to the northeast Pacific: Seasonal variations and transport pathways of carbon monoxide, J. Geophys. Res., 109, D23S07, doi:10.1029/2003JD004402, 2004.

Li, L., Chen, C. H., Huang, C., Huang, H. Y., Li, Z. P., Fu, S. J., Jang, J. C., and Streets, D. G.: Regional Air Pollution Characteristics Simulation of $\mathrm{O}_{3}$ and PM10 over Yangtze River Delta Region, Environ. Sci., 29(1), 237-245, 2008 (in Chinese).

Li, X. H., Duan, L., Wang, S. X., Duan, J. C., Guo, X. M., Yi, H. H., Hu, J. N., Li, C., and Hao, J. M.: Emission characteristics of particulate matter from rural household biofuel combustion in China, Energy \& Fuels, 21, 845-851, 2007.

Li, X. H., Wang, S. X., Duan, L., and Hao, J. M.: Characterization of non-methane hydrocarbons emitted from open burning of wheat straw and corn stover in China, Environ. Res. Lett., 4, 044015, doi:10.1088/1748-9326/4/4/044015, 2009.

Liu Q. S. and Yin, B. M.: Cement industry economic circumstance analysis in 2003 and prospects of 2004, China Building Materials, 1, 80-82, 2004 (in Chinese).

Makar, P. A., Moran, M. D., Zheng, Q., Cousineau, S., Sassi, M., Duhamel, A., Besner, M., Davignon, D., Crevier, L.-P., and Bouchet, V. S.: Modelling the impacts of ammonia emissions reductions on North American air quality, Atmos. Chem. Phys., 9, 7183-7212, doi:10.5194/acp-9-7183-2009, 2009.

NDRC (National Development and Reform Commission): energysaving in long-term and special program, Beijing, China, 2004 (in Chinese).

NDRC (National Development and Reform Commission): some suggestions on speeding up the cement industry structure adjustment, Beijing, China, 2006 (in Chinese).

NDRC (National Development and Reform Commission): longterm development plan of nuclear power (2005-2020), Beijing, China, 2007 (in Chinese).

NDRC (National Development and Reform Commission): "11th five-year" plan for renewable energy development, Beijing, China, 2008a (in Chinese).

NDRC (National Development and Reform Commission): innovation and development planning outline in PRD (20082020), National Development and Reform Commissison, Beijing, China, available at: http://politics.people.com.cn/GB/1026/ 8644751.html (last access: November 2010), 2008b.

NBSC (National Bureau of Statistics of China): Statistical communiqué of the People's Republic of China on the 2009 national economy and social development, Beijing, China, available at: http://www.stats.gov.cn/tjgb/ndtjgb/ qgndtjgb/t20100225_402622945.htm, 2010.

NPDSR (National Population Development Strategy Research): Research Report on National Population Development Strategy, Population Research, 31(1), 1-10, 2007 (in Chinese).

Richter, A., Burrows, P., Nues, H., Granier, C., and Niemeijer, U.: Increase in tropospheric nitrogen dioxide over China observed from space, Nature, 437, 129-130, 2005. 
Ohara, T., Akimoto, H., Kurokawa, J., Horii, N., Yamaji, K., Yan, X., and Hayasaka, T.: An Asian emission inventory of anthropogenic emission sources for the period 1980-2020, Atmos. Chem. Phys., 7, 4419-4444, doi:10.5194/acp-7-4419-2007, 2007.

Streets, D. G. and Waldhoff, S. T.: Present and future emissions of air pollutants in China: $\mathrm{SO}_{2}, \mathrm{NO}_{\mathrm{x}}$, and $\mathrm{CO}$, Atmos. Environ., 34, 363-374, 2000.

Streets, D. G., Zhang, Q., Wang, Z. F., Hao, J. M., Wang, B. Y., Li, Z. P., Tang, X. Y., Zhang, Y. H., Fu, J. S., He, K. B., Wang, L. T., Jang, C. J., and Yu, C.: Air quality during the 2008 Beijing Olympic Games, Atmos. Environ., 41, 480-492, 2007.

Tian, H. Z.: Studies on Present and Future Emissions of Nitrogen Oxides and its Comprehensive Control Policies in China. Tsinghua University, Beijing, PhD. dissertation, 2003.

Tsimpidi, A. P., Karydis, V. A., and Pandis, S. N.: Response of Inorganic Fine Particulate Matter to Emission Changes of Sulfur Dioxide and Ammonia: The Eastern United States as a Case Study, J. Air Waste Manage. Assoc., 57, 1489-1498, doi:10.3155/1047-3289.57.12.1489, 2007.

Unger, N., Shindell, D. T., Koch, D. M., and Streets, D. G.: Cross influences of ozone and sulfate precursor emissions changes on air quality and climate, P. Natl. Acad. Sci. USA, 103, 4377-4380, 2006.

Uno, I., He, Y., Ohara, T., Yamaji, K., Kurokawa, J.-I., Katayama, M., Wang, Z., Noguchi, K., Hayashida, S., Richter, A., and Burrows, J. P.: Systematic analysis of interannual and seasonal variations of model-simulated tropospheric $\mathrm{NO}_{2}$ in Asia and comparison with GOME-satellite data, Atmos. Chem. Phys., 7, 16711681, doi:10.5194/acp-7-1671-2007, 2007.

van Aardenne, J. A., Carmichael, G.R., Levy II, H., Streets, D., and Hordijk, L.: Anthropogenic $\mathrm{NO}_{\mathrm{x}}$ emissions in Asia in the period 1990-2020, Atmos. Environ., 33, 633-646, 1999.

Wang, C., Cai, W. J., Lu, X. D., and Chen, J. N.: $\mathrm{CO}_{2}$ mitigation scenario in China's road transport sector, Energy Convers. Manage., 48, 2110-2118, 2007.

Wang, S. X., and Zhang, C. Y.: Spatial and temporal distribution of air pollutant emissions from open burning of crop residues in China, Sciencepaper Online, 3(5), 329-333, 2008.

Wang, S. X., Wei W., Du, L., Li, G. H., and Hao, J. M.: Characteristics of Gaseous Pollutants from Biofuel-Stoves in Rural China, Atmos. Environ., 43(27), 4148-4154, 2009.

Wang, S. X., Zhao, M., Xing, J., Wu, Y., Zhou, Y., Lei, Y., He, K. B., Fu, L. X., and Hao, J. M.: Quantifying the Air Pollutants Emission Reduction during the 2008 Olympic Games in Beijing, Environ. Sci. Technol., 44(7), 2490-2496, doi:10.1021/es9028167, 2010.

Wei, W., Wang, S. X, Satoru, C., Klimont, Z., Cofala, J., and Hao, J. M.: Emission and speciation of non-methane volatile organic compounds from anthropogenic sources in China, Atmos. Environ., 42(20), 4976-4988, 2008.

Wei, W.: Research and Forecast on Chinese Anthropogenic Emissions of Volatile Organic compounds, Tsinghua University, Beijing, China, Doctor thesis, 2009.
Wei, W., Wang, S. X., Hao, J. M., and Cheng, S. Y.: Projection of Anthropogenic Volatile Organic Compounds (VOCs) Emissions in China for the period 2010-2020, Atmos. Environ., in press, doi:10.1016/j.atmosenv.2011.01.013, 2011.

Wild, O. and Akimoto, H.: Intercontinental transport of ozone and its precursors in a three-dimensional global CTM, J. Geophys. Res., 106, 27729-27744, 2001.

Xing, J., Wang, S. X., Chatani., S., Cofala, J., Klimont, Z., Amann, M., and Hao, J. M.: Validating Anthropogenic Emissions of China by Satellite and Surface Observations, Atmos. Environ., submitted, 2010.

Yamaji, K., Ohara, T., Uno, I., Kurokawa, J., Pochanart, P., and Akimoto, H.: Future prediction of surface ozone over east Asia using Models-3 Community Multiscale Air Quality Modeling System and Regional Emission Inventory in Asia, J. Geophys. Res., 113, D08306, doi:10.1029/2007JD008663, 2008.

Yi, H. H., Hao, J. M., Duan, L., Li, X. H., and Guo, X. M.: Characteristics of inhalable particulate matter concentration and size distribution from power plants in China, J. Air Waste Manage. Assoc., 56, 1243-1251, 2006.

Zhang, M., Uno, I., Zhang, R., Han, Z., Wang, Z., and Pu, Y.: Evaluation of the Models-3 Community Multi-scale Air Quality (CMAQ) modeling system with observations obtained during the TRACE-P experiment: comparison of ozone and its related species, Atmos. Environ., 40(26), 4874-4882, 2006.

Zhang, Q., Streets, D. G., Carmichael, G. R., He, K. B., Huo, H., Kannari, A., Klimont, Z., Park, I. S., Reddy, S., Fu, J. S., Chen, D., Duan, L., Lei, Y., Wang, L. T., and Yao, Z. L.: Asian emissions in 2006 for the NASA INTEX-B mission, Atmos. Chem. Phys., 9, 5131-5153, doi:10.5194/acp-9-5131-2009, 2009.

Zhao, Y., Wang, S. X., Duan, L., Lei, Y., Cao, P. F., and Hao, J. M.: Primary air pollutant emissions of coal-fired power plants in China: Current status and future prediction, Atmos. Environ., 42, 8442-8452, 2008.

Zhao, Y., Wang, S. X., Nielsen, C. P., Li, X. H., and Hao, J. M.: Establishment of a database of emission factors for atmospheric pollutants from Chinese coal-fired power plants, Atmos. Environ., 44(12), 1515-1523, 2010.

Zhao, Y., Nielsen, C. P., Lei, Y., McElroy, M. B., and Hao, J.: Quantifying the uncertainties of a bottom-up emission inventory of anthropogenic atmospheric pollutants in China, Atmos. Chem. Phys., 11, 2295-2308, doi:10.5194/acp-11-2295-2011, 2011.

Zheng, J., Zhang L. J., Che, W. W, Zheng, Z. Y., Yin, S. S.: A highly resolved temporal and spatial air pollutant emission inventory for the Pearl River Delta region, China and its uncertainty assessment, Atmos. Environ., 43, 5112-5122, 2009.

Zhu, F. H., Wang, S., and Zheng, Y. F.: $\mathrm{NO}_{\mathrm{x}}$ emitting current situation and forecast from thermal power plants and countermeasures. Chinese J. Energy Environ. Prot., 18, 1-5, 2004. 